\title{
Perinnetieteet JA PiIRROSten TIETO
}

\author{
Piirrosten asema Axel Olai Heikelin ja Elsa Enäjärvi-Haavion \\ tutkimuksissa
}

Kari Korolainen

Piirroksia on käytetty eri aikoina ja eri kulttuureissa lukuisiin tarkoituksiin. Niitä on hyödynnetty niin ikään suomalaisissa perinnetieteissä eli folkloristiikassa ja kansatieteessä, mutta piirrosten asemaa on pohdittu vähemmän tieteenalan tietokäsitysten kannalta. Perinnetieteiden piirissä piirroksia on käsitelty useimmiten alan tutkijoiden uraa tarkasteltaessa, kuten esimerkiksi U. T. Sireliuksen (Lehtonen 1972) ja Samuli Paulaharjun (Laaksonen 1999; Harju 1989) yhteydessä. Kansatieteellisen rakennustutkimuksen alalla muiden muassa A. O. Heikeliä ja U. T. Sireliusta pidetään uranuurtajina piirrosten soveltajina (Lehtonen 1972, 175). Myös perinnekartat voi ajatella yhtenä perinnetieteellisen, metodisen piirtämisen muotona (ks. Lehtipuro 1974, 25-26; Sarmela 1965; Haavio 1939). Taidepiirroksia taas on käytetty lähinnä perinnetieteiden aiheiden kuvittajina esimerkiksi niin sanotussa Kalevala-taiteessa tai karelianismissa (ks. Knuuttila 2010; 1978; Sihvo 2003). Perinnetieteiden lähialoista muun muassa arkeologiassa piirtämisellä on ollut merkittävä rooli.

Käsittelen kirjoituksessani piirrosten asemaa perinnetieteellisen tiedon tuottamiseen liittyvien kysymysten ja tutkimuskohteiden kuvailun kannalta. Esimerkiksi kulttuurintutkija Lawrence Grossberg $(2010,15)$ on tuonut esiin, että tiedon tuottamisen ehtojen kriittinen pohtiminen on muodostunut kulttuurintutkimuksen alalla tärkeäksi kysymykseksi jo varhain. Myös suomalaisissa perinnetieteissä aihetta on käsitelty eri painotuksin (esim. Knuuttila 2011; Vakimo 2008; Sääskilahti 1997; Turunen 1995). Edellisten lisäksi voidaan ajatella, että visuaalisuus on yhä enenevässä määrin tullut osaksi eri tutkimusalojen keskusteluja, mistä kirjallisuudentutkija 
W. J. T. Mitchell (1994, 11-34) käyttää "kuvallisen käänteen" käsitettä (kuvallisuudesta ks. Seppä 2007; Benjamin 2008 [1936]). Tähän taustaan tukeutuen pohdin kirjoituksessani, miten piirroksia on käytetty esimerkiksi tutkimuskohteiden kuvailemisessa. Ennen 1800-luvun puoliväliä tehtyjä piirroksia on tutkittu jonkin verran, joten olen rajannut varhaisimmat kuvalliset esitykset tutkimukseni ulkopuolelle (ks. Knapas \& Koistinen 1993). Käsittelen artikkelissani kansatieteilijä Axel Olai Heikelin ja folkloristi Elsa Enäjärvi-Haavion tutkimustyötä. Keskityn näihin tutkijoihin, sillä Heikelin ja Enäjärvi-Haavion tutkimuksissa näkyy kansatieteen ja folkloristiikan vuorovaikutus, vaikka heidän tutkimuksensa usein lähtivätkin liikkeelle kansanrunoihin liittyvistä kysymyksistä. Tarkastelen sitä, millaisia kategorioita "piirtäjä" ja "tutkija" ovat olleet Heikelin ja EnäjärviHaavion tuotantoon liittyvissä teksteissä. Toiseksi tutkin, millainen asema piirroksilla on kyseisten tutkijoiden tutkimusten retoriikassa niin kenttätyöaineistoissa kuin tulosten esittämisessäkin.

\section{MONTA NÄKÖKULMAA, KAKSI TUTKIMUSMENETELMÄÄ}

Vaikka artikkelin lähtökohtana ovat piirrokset, en tutki niitä yleisesti kuvallisuuden näkökulmista. Aihe sivuaa luonnollisesti monia visuaalisen tutkimuksen kysymyksenasetteluja. Kulttuurintutkimuksessa ja visuaalisen antropologian piirissä kuvallisuutta on käsitelty usein metodologisesta näkökulmasta, tosin keskittyen painokkaammin valokuviin tai elokuviin kuin piirroksiin (ks. Sinisalo 2005; Morphy \& Banks 1997; Marcus 1994; Söderholm 1982). En ole tekemässä myöskään niin sanottua graafista antropologiaa (Ingold 2011). Näkökulmavalintoihini on vaikuttanut se, että tutkimukseni kohteena on perinnetieteiden oppihistoria. Kirjoitukseni suuntautuukin nimenomaan perinteentutkimuksen alalle, kun taas tarkasteluni lähtökohdat ovat etnometodologisessa ja multimodaalisessa tutkimuksessa.

Yhteiskuntatieteen piirissä syntyneessä etnometodologiassa ilmiöitä tutkitaan teorialähtöisyyden sijaan tutkittavien ihmisten omista lähtökohdista, "jäsenten ilmiöinä" (Eglin \& Hester 2003, 4-9; Hilbert 1992, 51; ks. Heritage 1996). Etnometodologit Peter Eglin ja Stephen Hester (2003) ovat tutkineet esimerkiksi lehtikirjoittelussa käsiteltyä joukkomurhaa jäsenten ilmiönä, siis keskittyen siihen, miten kyseinen ilmiö hahmottuu lehtikirjoitteluun osallistuneiden ihmisten kannalta. Keskeistä etnometodologisessa otteessa on Harold Garfinkelin esittämä ajatus siitä, että arkista toimintaa tulisi tarkastella "jäsenten metodien" näkökulmasta. Käsite viittaa yleisesti niihin keinoihin, joilla ihmiset ylläpitävät toimintansa mielekkyyttä sekä sosiaalista järjestystä (Garfinkel 1967, vii-viii). Garfinkel (mts. 11-18) tutki tästä näkökulmasta esimerkiksi kuolinsyytodistus- 
ten laatimista nostaen esiin niitä konkreettisia perusteluja ja keinoja, kuten dokumenttien otsikointia tai kuolemaan johtaneiden seikkojen erittelyä, joilla viranomaiset taustoittavat todistusten tekemistä. Jäsenten metodien käsite on siis yleinen, tutkimusta suuntaava käsite. Perinteentutkija Seppo Knuuttila onkin huomauttanut, "[...] ettei etnometodologia sinänsä tarjoa minkään teoreettisen viitekehyksen valmista tutkimusmallia tai -menetelmää. Siinä tarkastelu nimittäin suuntautuu tutkimuskohteeksi valittujen subjektien kykyyn ja tapaan käsitellä erilaisia sosiaalisen elämän tuttuja, toistuvia asioita." (Knuuttila 1994, 69.)

Artikkelissani perinnetieteellisiä piirroksia tarkastellaan jäsenten ilmiönä, joten kiinnitän huomiota Heikelin ja Enäjärvi-Haavion tapoihin käyttää piirroksia. Jäsenyys viittaa näin tutkijoihin ja tutkijoiden yhteisöihin. Jäsenten metodit tarkoittavat tässä sitä, että olen kiinnostunut kaikista niistä tavoista, joilla kyseiset tutkijat piirroksia käyttivät tutkimuksissaan. Niinpä tarkasteluni lähtökohtana eivät ole teoriat, vaan ne käytännön keinot ja perustelut, joita Heikel ja Enäjärvi-Haavio itse käyttivät piirrosten yhteydessä.

Tutkijoiden tietokäsityksiin on kiinnitetty enemmänkin huomiota etnometodologisessa tieteen (työn) tutkimuksessa (esim. Lynch 1991 ja 1985; ks. Knuuttila 1994, 68-70). Michael Lynch (1991) on käsitellyt myös kuvallisia esityksiä tästä näkökulmasta ja havainnollistanut muun muassa sitä, miten piirrokset voivat asemoida argumentointia (mts. 12). Tiedon tuottamisen käytäntöjä yleisemmältä kannalta käsitellyt Jonathan Potter (1996) taas on vertaillut sosiologista tieteen tutkimusta, etnometodologiaa sekä semioottisia ja post-strukturalistisia suuntauksia. Itse olen kiinnostunut piirrosten käytäntöjen lisäksi siitä, millaisissa konteksteissa tutkijat ovat käyttäneet piirroksia. Tarkastelenkin aluksi, miten Heikelin ja Enäjärvi-Haavion tutkimukset paikantuvat oppihistoriallisissa teksteissä. Lisäksi tutkin, miten piirtäjät ja tutkijat tuodaan esiin näissä keskusteluissa. Tässä tukeudun kategorisonnin tutkimukseen (jäsenkategorisoinnin analyysi). Se on etnometodologian sovellus, jossa keskitytään puheen ja tekstien käytäntöihin (ks. Jokinen, Juhila \& Suoninen 2012; Korolainen 2012; Eglin \& Hester 2003).

Kategorisointi on kieleen liittyvää toimintaa, jonka puitteissa luokitellaan niin ihmisiä, esineitä kuin muitakin ilmiöitä (esim. Järviluoma ja Roivainen 1997, 15; Korolainen 2012, 34-36). Erittelen sitä, millaisia ominaisuuksia piirtäjiin on liitetty perinnetieteellisen tutkimuksen piirissä. Keskityn niin sanottuihin kategoriapiirteisiin ja kategoriasidonnaisiin toimintoihin. Kategoriapiirteellä viitataan kategoriaa määrittäviin ominaisuuksiin, kun taas kategoriasidonnainen toiminto voidaan ymmärtää erilaisina kategorioihin liitettyinä toimintoina, tehtävinä ja odotuksina. (Ks. Korolainen 2012, 32-37; Baker 2004, 167; Järviluoma \& Roivainen 1997, 17.) Jos 
esimerkiksi perinteentutkijasta käytetään kategorisointia "kansatieteilijä", korostetaan sitä, että henkilö kuuluu kansatieteen piiriin eikä niinkään folkloristiikan alalle. Näin "kansatieteen piiriin kuuluminen" muodostuu keskeiseksi kategoriapiirteeksi. "Tutkimuksen tekeminen" on puolestaan kansatieteilijä-kategorian keskeinen kategoriasidonnainen toiminto. Kansatieteilijän voi odottaa tekevän tutkimusta ennemminkin kuin tekevän taideteoksia. Aina kategorioiden ominaisuudet ja toiminnot eivät ole näin yksioikoisia. Voi pohtia muun muassa, mitä piirtäjän kategorisoiminen "taiteilijaksi" tarkoittaa tutkimuksen kontekstissa.

Oppihistoriallisten kategorisointien analysointi toimii artikkelissani piirrosten tutkimisen taustoituksena, mutta tavoitteena on myös valottaa yleisemminkin niitä tapoja, joilla piirroksista ja piirtäjistä on keskusteltu perinnetieteissä. Artikkelin jälkimmäisessä osassa keskitytään taas piirrosten aseman tarkasteluun. Painotan tällöin piirrosten ja tekstin suhdetta, koska tutkimuksen kohteena on perinnetieteellisiä, kirjallisia julkaisuja. Yleisenä lähtökohtana on Mitchellin (1994, 4) esiin nostama ajatus siitä, että vaikka ajattelisimme kuvalla ja sanalla olevan eroja, kuvan ja sanan suhdetta ei tulisi kuitenkaan yksinkertaistaa (ks. myös Mikkonen 2005). Tämä tarkoittaa sitä, etten pidä piirroksia lähtökohtaisesti pelkästään kuvituksena. Sen sijaan piirrokset ovat monisyinen kuvallinen ilmaisukeino. Kulttuuriteoreetikko Roland Barthesin mukaan piirroksissa kuvatut kohteet näyttäytyvät eri tavalla kuin valokuvassa, koska piirrokset eivät ole samalla tavoin automaattisia kuin kameran välittämät valokuvat. Hän korostaa, että piirrokset ovat osittaisia, sillä piirtäjä valitsee ne asiat, joita kuvassa esiintyy ja sen, kuinka tarkasti asioita esitetään. (Barthes 1977, 43; ks. Sinisalo 2005, 227.) Aiheeni kannalta olennaista tässä on se, että piirrokset ovat käsityötä: ne eivät synny nappia painamalla. Piirrosten osittaisuus puolestaan on kiinnostava kysymys tutkimuspiirtämisen tarkkuuden kannalta.

Etnometodologia ei sinällään tarjoa analyyttisia työkaluja tekstin ja kuvan suhteen tutkimiseen, joten tukeudun muihin kuvan tutkimuksen menetelmiin. Etnometodologisen tutkimuksen aineistolähtöisyys toimii tarkasteluni yleisenä viitekehyksenä, ja analyysin käytännöllisinä välineinä hyödynnän multimodaalisen tutkimuksen käsitteitä. Analyysin lähtökohtana on Barthesin esittämä ankkuroinnin (anchorage) käsite, joka viittaa siihen, että teksti suuntaa kuvien merkitysten luentaa, kun se tarjoaa näkökulmaa toiselta tasolta kuin kuva. Esimerkiksi kuvatekstit voivat ankkuroida kuvien merkitystä täydentäessään niiden tulkintaa. (Ks. Barthes 1977, 38-41; Mikkonen 2005, 58.) Analyysissani erittelenkin niitä tapoja, joilla tekstiä ja piirroksia ankkuroidaan yhteen. Kirjallisuudentutkija Kai Mikkosen (2005, 57-72) mukaan bartheslainen kuvan ja sanan teoria on yksinkertaisuudessaan helposti lähestyttävä, mutta samalla myös kuvan 
ja sanan vastakkaisuus korostuu painokkaasti. Tavoitteenani on lähestyä tekstin ja piirroksen suhdetta kokonaisvaltaisemmin ja etnometodologisissa lähtökohdissa pitäytyen, mistä syystä hyödynnän ankkurointien tarkastelun rinnalla multimodaalista tutkimusotetta. Gunter Kress ja Theo Van Leeuwen ovat hakeutuneet poispäin bartheslaisesta ajattelusta kyseistä tutkimussuuntausta kehitellessään (Kupiainen 2007, 40-41; Kress \& van Leeuwen 2006, 17-18). Multimodaalisessa tutkimuksessa hahmotetaan monista eri keinoista (engl. mode), kuten tekstistä, kuvasta tai äänestä koostuvia esityksiä (Jewitt 2009a, 14, 22; ks. Kress 2010, 15, 79-83; Kress 2009). ${ }^{1}$

Keskityn sellaisiin multimodaalisen tutkimuksen käsitteisiin, joiden avulla voi syventyä kuvan ja tekstin moniulotteisuuden suhteen analysointiin sekä havainnollistaa piirrosten asemaa tutkimuskohteen kuvailun kannalta. Hyödynnän analyysissani erityisesti sommitteluun liittyviä käsitteitä, joista Kress ja van Leeuwen (2006, 175-210) erittelevät muun muassa tietoarvon (information value), huomioarvon (salience) ja rajauksen (framing). Tietoarvo viittaa siihen, miten sommittelun elementtien tilallinen sijoittuminen (ylhäällä - alhaalla, oikealla - vasemmalla, keskikohdassa - reunassa) vaikuttaa tiedon välittymiseen. Kress ja van Leeuwen tarkastelevat esimerkiksi aikakauslehtien ja internetsivustojen elementtien sijoittelua: kuva tai teksti voi toimia "annettuna" tai "uutena" sivun sommitelman näkökulmasta. Tiivistäen sanottuna, vasemmalta oikealle tapahtuvan lukusuunnan kulttuurisessa kehyksessä lehden artikkeli voi rakentua tiedollisesti niin, että uudet asiat oikealla seuraavat vasemmalla jo annettuja asioita. (Mts. 179-201.) Syvennyn tietoarvon osalta siihen, miten piirrokset tuottavat uutta tietoa tutkimuksissa. Huomioarvolla Kress ja van Leeuwen viittaavat esitysten elementtien kykyyn herättää huomiota (mts. 177, 201-203). Ymmärrän huomioarvon erityisesti kuvan ja tekstin painotuksina, joten analysoin käsitteen avulla sitä, mitä tutkimuskohteesta kulloinkin nostetaan esiin piirroksia käyttämällä. Rajaaminen viittaa taas siihen, miten sommittelun elementit, esimerkiksi teksti ja kuvat liittyvät toisiinsa tai miten niitä on erotettu (mts. 177, 203-204).

Tarkastelen myös kuvien "topologisia prosesseja", joilla Kress ja van Leeuwen (2006, 98-100) tarkoittavat sitä, miten joissakin esityksissä, kuten kartoissa ja sähkökaavioissa, kuvataan (topologisesti) asioiden suhteita ja toimintaperiaatteita. "Objektiivisten kuvien" käsitteellä taas viitataan muun muassa sellaisiin kuviin, joissa aihe on esitetty ylhäältä päin katsottuna (mts. 143-148). Kartat tai kaaviot voivat olla siis sekä topologisia että objektiivisia kuvia. Olennaista topologisten ja objektiivis-

\footnotetext{
${ }^{1}$ Multimodaalisen tutkimuksen eri lajeista ks. Jewitt 2009b. Multimodaalisesta tutkimuksesta keskusteltiin myös Kansatieteen päivillä (13.-14.4.2014) Helsingissä Jyrki Pöysän ja Tytti Steelin vetämässä työryhmässä "The Concept of Multimodality as a Tool for Analysis". Olen kiitollinen Jyrki Pöysälle aihepiiristä ja työryhmästä muistuttamisesta.
} 
ten kuvien käsitteissä on huomion kiinnittäminen siihen, miten esitystapa vaikuttaa aiheen käsittelyyn. Pohtimisen arvoista on esimerkiksi se, mitä eroa kaavioilla ja esittävillä perspektiivikuvilla on perinnetieteellisten tutkimuskohteiden kuvailun kannalta.

\section{TUTKIMUSAINEISTOT}

Kansatieteilijä Axel Olai Heikelin (1851-1924) ja kuvataiteilija Agathon Reinholmin (1857-1887) yhteistyö on ensimmäisen aineistokokonaisuuden lähtökohta. Tarkastelen erityisesti julkaisuja ja dokumentteja liittyen Heikelin ja Reinholmin vuonna 1880 tekemään Karjalan tutkimusmatkaan. Aineistonani on retken valmisteluun liittyviä SKS:n pöytäkirjoja (SKS:n Keskustelemukset 1881; 1883; 1885), Theodor Schvindtin ja Heikelin vuonna 1888 Heikelin tutkimuksista käymä keskustelu Valvojassa (Schvindt 1888a ja b; Heikel 1888b) sekä joitakin Heikelin lehtikirjoituksia Uudessa Suomettaressa. Lisäksi olen tarkastellut Heikelin ja Reinholmin asemoitumista useissa oppihistoriaa käsittelevissä tutkimuksissa. Heikelin julkaisuista keskeisiä ovat Kansatieteellinen sanasto kuvien kanssa (1885) sekä väitöskirja Rakennukset tšeremisseillä, mordvalaisilla, virolaisilla ja suomalaisilla (1887). ${ }^{2}$ Näiden teosten käsittelyn rajaan kuvauksiin eteläkarjalaisesta uunista (1885, 16-22; 1887, 223-228). Myös Kalevalan (1887, 473, 487, 489) kuvitetun painoksen liitteissä sekä Kalevalan selityksissä on käytetty osin samoja kuvauksia (Kalevala. II. 1895, liite 3, 16-17; Niemi 1910, 74). Arkistodokumenteista keskeisimpiä ovat Heikelin kirjoitus "Kansatieteellisiä tutkimuksia Karjalasta" ja sen aiempi käsikirjoitusversio (SKS Jpa Heikel 84 ja 78) sekä näihin liittyvät Reinholmin piirrokset (SKS KRAK 1880:E 85). Täydentävinä aineistoina on Heikeliä ja Reinholmia koskevia käsikirjoituksia, muistiinpanoja ja piirroksia Museoviraston Kansallismuseon kansatieteellisen arkiston sekä kuva-arkiston kokoelmista (MV KM:K1012; MV KK1120:1-155). ${ }^{3}$

Toinen aineistokokonaisuus keskittyy Elsa Enäjärvi-Haavion (1901-1951) Pankame käsi kätehen -tutkimuksen (1949) ympärille. Aineisto ei ole kokonaisuutena yhtä kattava kuin Heikelin kohdalla, koska EnäjärviHaavion tutkimuksen taustalla ei ollut samanlaista laajempaa tutkimushanketta ja siitä käytyä keskustelua. Lisäksi Reinholmin piirroksia käytettiin useissa Heikelin julkaisuissa, joten tilanne on erilainen kuin EnäjärviHaavion yhteydessä. Analysoin Enäjärvi-Haavionkin osalta teoksen lisäksi

\footnotetext{
${ }^{2}$ Molemmat tutkimukset on julkaissut Suomalaisen Kirjallisuuden Seura sekä Suomisarjassa että eripainoksina. Käytän tässä Suomi-sarjassa julkaistuja versioita. Väitöskirjasta on julkaistu myös saksankielinen painos Suomalais-ugrilaisen Seuran Aikakauskirjassa (No 4) (Heikel 1888a).

${ }^{3}$ Museoviraston Kansallismuseon Kulttuurien Museon arkistossa (MV KMA) on myös esimerkiksi Reinholmin piirroksia.
} 
myös tutkimuksen vastaanottoa ja paikantumista oppihistoriassa. Pankame käsi kätehen -teoksesta tarkastelen kahta katkelmaa: ensiksi pohdin, miten Enäjärvi-Haavio käyttää piirroksia argumentoinnissaan osoittaessaan käsityksen vastatusten tapahtuvasta runonlaulusta vääräksi (mts. 56-72). Toisessa esimerkissä keskityn siihen, miten Enäjärvi-Haavio sovelsi omia piirroksiaan naisten ryhmälaulutapojen selvittämisessä (mts. 158-159). Lisäksi aineistona on kyseiseen tutkimukseen liittyviä käsikirjoitusdokumentteja (SKS KIA Enäjärvi-Haavio I. 4. ja I. 5) sekä perinneaineistoja Viroon suuntautuneelta kenttämatkalta vuodelta 1936 (SKS Jpa Enäjärvi-Haavio). Retki oli yhtenä lähtökohtana teoksessa olevalle naisten ryhmälaulutapojen selvittelylle.

\section{TUTKIJOIDEN, PIIRTÄJIEN JA TUTKIMUSTEN ASEMOITUMINEN PERINNE- TIETEISSÄ}

Heikeliä pidetään suomalaisen etnologian "pioneerina" (Niiranen 1992, 21-22; ks. Vuorela 1977, 39-44) ja typologisoivan menetelmän uranuurtajana (Niiranen 1992, 29; ks. myös Niiranen 1987). Pioneeri-kategoriaan liittyy kategoriapiirteenä edistyksellisyys ja kategoriasidonnaisena toimintona etnologian tutkimusalan laajentaminen. Oppihistoriallisissa teksteissä Heikelin "kansatieteilijyydessä" on erilaisia painotuksia, sillä hänellä oli arkeologitausta ja hänen merkityksensä museomaailmassa on ollut huomattava (Turunen 1995, 31; Niiranen 1987, 51-62; 175-188; Vuorela $1977,39)$. Heikelin kuuluminen museomaailmaan ennemmin kuin yliopistomaailmaan painottuu esimerkiksi "museomies"-kategorisoinnissa (ks. Heikel 1989). Oppialan paikantumisia kriittisesti käsitellyt kansatieteilijä Nina Sääskilahti (1997; ks. myös 1999) on tuonut esiin, että "[v]aikka Heikelin tuotanto on vaikeasti luokiteltavissa nykyisen oppialajaottelun mukaisesti, häntä nimitetään kansatieteen historioissa yksioikoisesti 'kansatieteilijäksi'" (Sääskilahti 1997, 20). Heikelin ote oli "kokonaisvaltainen", kuten kansatieteilijä Timo Niiranen $(1987,71)$ on todennut.

Perinnetieteiden toimijoiden asemaa ja oppialojen suhteita on painotettu oppihistorioissa eri tavoin. 1800-luvun loppupuolta on pidetty kansanrunoudentutkimuksessa esimerkiksi "valtavan murroksen" kautena (Haavio 1931, 55) sekä alan tieteellistymisen ja oppialojen eriytymisen aikana (Turunen 1995, 34, 152). Nykyäänkin kyseinen ajanjakso näyttäytyy muutoksen aikana, vaikkei tieteellistymistä välttämättä korosteta yhtä painokkaasti kuin aiemmin (Siikala 2013, 42). Tieteellistyminen ilmeni tuolloin muun muassa erilaisissa hankkeissa, kuten 1870-luvulla käynnistetyssä Kalevalan toisintojen toimittamishankkeessa (Sihvo 2003, 169; Hautala 1954, 171-173, 197-203). Suomalaisen Kirjallisuuden Seuran (SKS), kuten muidenkin perinnetieteellistä tutkimusta lähellä olevien 
seurojen vaikutusta tutkimusten ja hankkeiden taustalla voi pitää merkittävänä (esim. Sulkunen 2004; Sihvo 2003, 249; Turunen 1995, 152; Lehtipuro 1974, 7; Haltsonen 1947, 47-48; Haavio 1931, 87).

Myös Reinholmin asema oppihistorioissa on moniulotteinen. Kulttuurihistorioitsija Hertta Tirranen (1960, 71) nimeää hänet "kansatieteelliseksi piirtäjä-avustajaksi", mikä on kiinnostava kategorisointi, sillä Reinholmin asema piirtäjänä tulee esiin täsmällisemmin kuin usein hänen yhteydessään käytetyssä taiteilija-kategoriassa. Kansatieteeseen kytkeytyminen tulee esiin keskeisenä kategoriapiirteenä, ja avustaminen kategoriasidonnaisena toimintona määrittää tässä piirtämisen nimenomaan tutkimusta avustavaksi toiminnaksi. Lisäksi Tirranen toteaa muun muassa, että tutkimuksellinen kehys rajoitti "[...] piirtäjän taiteellista vapautta [...]" (mts. 70-71) ja että "Reinholm toimi jossain määrin myös vapaana taiteilijana [...]" (mts. 81). Taiteeseen kytkeytyy vapaus kategoriapiirteenä, samalla kun tutkimus näyttäytyy tätä vapautta rajaavana asiana. Kansatieteilijä Ildikó Lehtinen $(2004,47)$ käyttää Reinholmin yhteydessä taitelija-kategorian lisäksi esimerkiksi ilmausta "havaintojen tekijä" (mts. 51). Lehtinen (mts.) toteaa myös: "Sen ajan marilainen ja mordvalainen todellisuus avautuu silmiemme eteen Heikelin suodattimen läpi, mutta Reinholmin silmin nähtynä". Nämä ovat tärkeitä huomioita tutkijan ja taiteilijan yhteistyötä mietittäessä. Piirtäjän rooli tutkimusprosessissa voidaankin nähdä Reinholmin osalta suurempana kuin miten se artikkelissani tarkastelluissa tutkimusjulkaisuissa usein ilmenee.

Toisin kuin Heikel, Enäjärvi-Haavio ei tiettävästi käyttänyt taiteilijoiden apua tutkimukseensa liittyvissä kenttätöissä. Kategorisointien tarkastelun lähtökohta on Enäjärvi-Haavion kohdalla hieman erilainen, koska hänellä ei ollut samanlaista työparia kuin Reinholm oli Heikelille. Outi Lehtipuro (1974, 15) paikantaa Pankame käsi kätehen -tutkimuksen ensisijaisesti "laulajan roolin" tutkimiseen. Tutkimuksen ansioina on nähty esimerkiksi argumentoinnin realistisuus. Kirjallisuudentutkija Risto Turunen (1996, 84-85) korostaa tähän liittyen muun muassa "[...] siirtymistä historiallisesta ja myytillisestä spekulaatiosta ilmiöiden todennettavissa olevaan kontekstuaaliseen tarkasteluun". Enäjärvi-Haavion yhteydessä on kiinnitetty huomiota lisäksi naisten asemaan perinnetieteissä. Muiden muassa folkloristi Irma-Riitta Järvinen (1991, 44-48) nostaa esiin sekä sukupuolikysymyksen että leikit tutkimuksen kohteena. Risto Turunen paikantaa naisten roolin kasvamisen perinnetieteissä 1920-luvulle ja heti toisen maailmansodan jälkeisiin vuosiin ja pitää Enäjärvi-Haaviota uranuurtajana (Turunen 1995, 84, 94; ks. Turunen 1996, 85; myös Vakimo 2008, 6-7). Samanlaisiin paikannuksiin päätyy perinteentutkija Merja Leppälahti (Järviseen ja Turuseen viitaten) $(2005,44)$. Leikki tutkimuksen kohteena tulee esiin sellaisissa perinteentutkimuksen avartumistakin painottavissa 
kategorisoinneissa kuin "leikintutkija" (Turunen 1996, 80) tai "leikkitohtori" (Leppälahti 2005, 34-48). Enäjärvi-Haavion tutkimuksia on käsitelty hiljattain kansantanssin tutkimuksen yhteydessä, mitä kautta hän asemoituu tänäkin päivänä perinteentutkimusta avartavalle linjalle (ks. Aronen 2014).

Tutkijoiden ja piirtäjien asemoitumisen analyysi tuo esiin, miten kategorisointien näkökulmasta Heikelin ja Enäjärvi-Haavion paikantumisessa perinnetieteiden piiriin voi löytää vivahde-eroja, vaikka jotkin kategorisoinnit näyttävät toistuvan, kuten pioneeriasema Heikelin ja leikkitutkimus Enäjärvi-Haavion kohdalla. Reinholmin rooli ei sekään ole aivan yksioikoinen, vaikka avustajana hänen asemansa näyttää jäävän vähemmälle huomiolle tutkimuksista käydyissä keskusteluissa.

Henkilöiden paikantumisen lisäksi on syytä tarkastella tarkemmin myös sitä, miten Heikelin ja Enäjärvi-Haavion tutkimukset asemoituvat oppihistorioissa. Heikelin ja Reinholmin Karjalan retken taustalla oli SKS:n organisoima Kalevalan kuvitushanke. Se on saanut runsaasti huomiota perinnetieteiden oppihistorioissa eri aikoina (esim. Sulkunen 2004, 192194; Lehtinen 2004, 49; Sihvo 2003, 234-235; Niiranen 1987, 37-40; Vuorela 1977, 40; Tirranen 1960, 70-72; Haltsonen 1947, 47-50; Haavio 1931, 85-86). Seuran sihteeri F. W. Rothsten esitti Kalevalan kuvittamista seuran kokouksessa 24.4.1880. Hän mainitsee keskustelleensa asiasta unkarilaisen professori J. Budenzin kanssa, joka oli esittänyt idean kuvittamisesta jo aiemmin. (SKS:n Keskustelemukset 1881, 395.) Piirrosten ja niihin liittyvien kategorisointien kannalta merkillepantavaa kuvitushankkeen valmistelussa on pohdinta kuvitusten tieteellisyydestä ja taiteellisuudesta (SKS:n Keskustelemukset 1881, 401-402; ks. myös Haltsonen 1947, 48). Hanketta valmistelleen toimikunnan lausunnossa vaihtoehdot tulevat esiin:
Kalevalan kuvilla varustamista voidaan yleensä kahdella eri ta- valla toimeen panna, joko suorastaan taiteellisesti niin että sii- hen hankitaan yhdeltä tai useammalta taideniekalta itsenäisesti luotuja kompositioneja, taikka siten että toimitetaan luonnon- mukaisia piirustuksia runoissa mainituista kansatieteellisistä esineistä (SKS:n Keskustelemukset 1881, 401).

Tieteen ja taiteen erot ilmenevät selkeästi lausunnossa. Kuten taidehistorioitsija Hanna Pirinen (2012) tuo esiin, taidesanaston muotoutuminen oli yksi 1800-luvun lopulla käynnissä olleista prosesseista. SKS:n lausunnon taiteellisessa vaihtoehdossa taideniekka-kategoria tarkoittaa siis taiteilijaa (mts. 91). Lausunnon ilmaisua "luonnon-mukainen" voidaan pitää tieteeseen viittaavana, sillä se rinnastuu myöhemmin pöytäkirjassa ilmaisuun "etnografilliset kuvat" sekä perusteluihin hankkeen tärkeydestä "tieteen kannalta" (SKS:n Keskustelemukset 1881, 401, 402). Tieteellinen ja taiteellinen toimintapa ovat tässä SKS:n toimintaan osallistuneiden 
tutkijoiden muotoilema jako (jäsenten metodi), jolla taide asemoidaan vastakohdaksi tieteelliselle vaihtoehdolle. Taiteilijan kategoriapiirteet ja taiteilijan toiminnan käytännöt tulevat esiin alun ilmauksessa "luoda itsenäisesti". Taiteelliset kuvat ovat vapaampia kuvia, kun taas realistiset kuvat ovat nimenomaan piirroksia esineistä. Näin ollen vapaus mutta myös itsenäisyys ovat taiteilijan toimintaa määrittäviä kategoriapiirteitä. Toimikunta päätyi lopulta luonnonmukaisen vaihtoehdon kannalle muun muassa taiteellisen vaihtoehdon kalleuden takia (mts. 401-402).

Heikelin (1885, iii) Kansatieteellisen sanaston esipuheessa kuvitushanke hahmottuu "kansatieteellisenä tutkimuksena", joten SKS:n pöytäkirjojen yhteydessä mainittu ilmaus "luonnon-mukaisuus" on jäänyt pois prosessin myötä. Nyt puhutaan nimenomaan kansatieteestä. Tässä yhteydessä myös piirrosten tekijä tulee esiin: "Piirustajana seurasi mukanani nuori taiteilija A. Reinholm, joka tällä matkalla teki yli 300 kuvan" (mts.). Heikel kategorisoi Reinholmin tutkimusmatkan "piirtäjäksi", mutta samalla käyttää hänestä titteliä "nuori taiteilija". Reinholmin tehtävä piirtäjänä (kategoriasidonnainen toiminto) tulee selvästi esille, mutta nuori taiteilija -kategorisointia ei kuitenkaan perustella. Silti taiteilija-kategoria tuo esiin taidemaailman kontekstin (kategoriapiirre), joka aiemmin SKS:n lausunnossa erotettiin tieteestä. Taiteilija-kategoriaan liitetään ominaisuus "piirtäminen", jolloin "taiteilija" viittaa erityisesti kuvataiteen traditioon, jossa piirtämisellä ja esittävällä esitystavalla on keskeinen sija.

Heikelin ja Reinholmin työnjako toistuu vaihdellen oppihistoriallisissa teksteissä. Heikelin $(1920,68)$ muistokirjoitus nuorena kuolleesta Reinholmista on kiinnostava sikäli, että siinä kyseinen retki liittyy "Kalevalatutkimukseen". Kansatieteellisessä sanastossahan (1885, iii) Heikel kirjoitti "kansatieteellisestä tutkimuksesta" (vrt. "luonnon-mukaisuus"). Retken tutkimuksellinen luonne vahvistuu kuitenkin eri teksteissä toistuvan tutkimuspainotuksen myötä. Toivo Vuorelan (1977) etnologiaa käsittelevässä tutkimuksessa nousee esiin myös Severin Falkman, jota ehdotettiin aluksi hankkeen piirtäjäksi (SKS:n Keskustelemukset 1881, 402-403; vrt. 409; ks. myös Sulkunen 2004, 193; Sihvo 2003, 235). Heikelin matkaraportista käy ilmi, että alussa Falkman oli ollut mukana, mutta myöhemmin hän erosi ryhmästä (ks. SKS:n Keskustelemukset 1881, 447-448).

Thus, Heikel now had the change of accompanying the student A. Reinholm on a long collecting tour of southern Carelia in 1880. Severin Falkman acted as illustrator to the expedition. The folklorist, A. A. Borenius (Lähteenkorva), had drawn up instructions under ten headings for the party. (Vuorela 1977, 40.)

Vuorelan esimerkki havainnollistaa retkestä kertomisen sanallisen muodon kiteytymistä. Retken osallistujat, Severin Falkman mukaan lukien, SKS rahoittajana sekä Borenius ohjeiden laatijana toistuvat Heikelinkin (1920, 
68) muistokirjoituksessa. Rakenteeltaan samanlaisia kuvauksia tapaa useiden kansatieteilijöiden teksteissä, kuten Sulo Haltsoseen $(1947,49)$ tukeutuvalla Timo Niirasella $(1987,37)$ sekä Ildikó Lehtisellä $(2004,49)$. Osin tämä "kaava" löytyy jo Schvindtin $(1888 a, 466)$ kritiikissä Valvojassa. Yllä Vuorelan esimerkkikatkelmassa Falkmanin osuus korostuu kuvitustehtävän esiin tuomisessa. Boreniuksesta käytetty kategorisointi "folkloristi" vahvistaa tiedemaailman roolia (kategoriapiirre) sekä "ohjeiden laatimisen" (kategoriasidonnainen toiminto) myötä myös sen normatiivista valtaa. Edellisistä poiketen kirjallisuuden- ja historiantutkija Hannes Sihvo käyttää ilmausta "kansatieteellinen kuvataide" käsitellessään retkeä taiteilijoiden karelianismin yhteydessä (Sihvo 2003, 233235). Sihvon ilmaus on välimuoto edellä käsitellyn kansatieteellisyyden ja taiteellisuuden välillä.

Yhteistä Heikelin tutkimuksille ja Enäjärvi-Haavion (1949) Pankame käsi kätehen -tutkimukselle on se, että tutkimuksissa käsitellyt kuvat liittyvät pitempiaikaisiin kuvallisiin jatkumoihin: Reinholmin piirrokset ovat tehneet kalevalaista maailmaa näkyväksi erityisesti Kalevalan selityksissä (ks. Niemi 1910; Kalevala. II. 1895; Kalewala 1887). Enäjärvi-Haavion (1949, 72) käsittelemät kuvat taas liittyvät laajalle levinneisiin käsityksiin runonlaulutavoista. Kuten Heikelillä, myös Enäjärvi-Haaviolla lähtökohtana oli jonkin toisen henkilön tekemä aloite tutkimuskohteen muotoilussa. Ruotsalainen etnologi John Granlund oli henkilökohtaisesti pyytänyt Enäjärvi-Haaviolta tietoja runojen laulutavoista (mts. 5). Enäjärvi-Haavion tutkimus ei kuitenkaan jää pelkästään selvitykseksi, vaan useisiin lähteisiin tukeutuen hän osoittaa, miten käsitys käsistä kiinni pitäen ja vastakkain huojuen tapahtuvasta runonlaulusta on syntynyt ja miksi käsitys on hänen mielestään väärä.

Runonlaulukäsityksen muodostumista selvittäessään Enäjärvi-Haavio (1949, 35-72) tukeutuu ennen kaikkea G. Acerbin ja A. F. Skjöldebrandin teosten runonlaulua esittäviin kuviin, jotka julkaistiin heti 1800-luvun alussa. Tämän jälkeen hän tarkastelee (mts. 73-119) eri lähteisiin, kuten piirroksiin ja valokuviin nojautuen, miten käsitys kaksinlaulusta levisi ja vakiintui. Enäjärvi-Haavio (mts. 9) kategorisoi Acerbin ja Skjöldebrandin "kahdeksi ulkomaalaiseksi matkailijaksi", joiden piirrosten pohjalta "tunnuskuva" vastakkain istuvista runonlaulajista on muodostunut. Skjöldebrandin hän (mts. 36) nimeää muun muassa "everstiksi", "kreiviksi", sotilaaksi", "hovimieheksi" sekä "taiteenharrastajaksi" ja "kynänkäyttäjäksi", kun taas Acerbin pelkästään "pääkonsuliksi". Tekstistä ei tosin selviä tarkoittaako "kynänkäyttäjä" piirtäjää tai taitelijaa. Kategorisoinnit havainnollistavat kuitenkin, ettei Enäjärvi-Haavion mukaan kyse ollut perinteentutkijoista tai kansatieteilijöistä vaan pikemminkin yläluokkaisista tutkimusmatkailijoista. 
Pankame käsi kätehen -tutkimus on saanut paljon huomiota osakseen heti ilmestyttyään ja myöhemminkin. ${ }^{4}$ Aikalaisista A. O. Väisänen (1948) kirjoitti jo hieman aiemmin samasta aiheesta. Hän täydensi vuonna 1949 tutkimustaan ja kritisoi Enäjärvi-Haavion esitelmässä esittämiä näkemyksiä runonlaulutavoista (ks. Väisänen 1990 [1949], 85). Myös Otto Andersson (1936) oli kirjoittanut runonlaulutavoista jo aiemmin. Enäjärvi-Haavio mainitseekin nämä kirjoitukset jo tutkimuksensa alkuvaiheessa (ks. 1949, 9, 12; alaviitteissä sivuilla 24, 47 ja 183). Anderssonin, Väisäsen ja Enäjärvi-Haavion tutkimukset ovat samankaltaisia aiheensa ja osin aineistoesimerkkiensä sekä erityisesti kuvaesimerkkien puolesta. EnäjärviHaavio ei siis ollut ainoa joka hyödynsi piirroksia. ${ }^{5}$

Folkloristeista Matti Kuusi (1949, 152-153) piti Pankame käsi kätehen tutkimusta "sensaatiomaisena", koska siinä osoitetaan kaksinlaulannan "väkikapulan vetoa muistuttava" asento vääräksi. Jouko Hautala (1954, 378-383) käsittelee samaa tutkimusta oppihistoriansa "Nykyhetken suomalaista kansanrunoudentutkimusta" -otsikon alla ja paikantaa Enäjärvi-Haavion myös kansanleikkien tutkijaksi (mts. 378; ks. Turunen 1995, 86-87). Hautala (1954, 381) kuvailee Kuusen tavoin EnäjärviHaavion tutkimusta ylistävin sanoin esimerkiksi "tieteellisen tutkimuksen mallinäytteeksi". Tällaisten kategorisointien perusteella tutkimus voidaan kytkeä perinnetieteiden murroksiin ja tieteellistymisiinkin.

Tutkimuksen jälkimmäisessä osiossa naisten ryhmälaulannan yhteydessä on kolmen Enäjärvi-Haavion itsensä tekemän piirroksen ryhmä laulutapojen askelkaavioista. Käsittelen näitä piirroksia tarkemmin seuraavassa alaluvussa (ks. kuva 5). Kategorisointien kannalta kiinnostavaa on, että tutkimuksensa alkuosassa runonlaulukuvia käsitellessään Enäjärvi-Haavio käyttää erilaisia kategorisointeja kuvien tekijöistä. Omien piirrostensa kohdalla hän ei kuitenkaan mainitse itseään piirrosten tekijänä huolimatta siitä, että piirroksilla on tutkimuksen argumentoinnin kannalta tärkeä asema.

Kategorisointien tarkastelu osoittaa, ettei oppialajaotteluja ja henkilöiden paikantamisia voi pitää yksiselitteisen selkeinä asioina tarkasteltaessa oppihistoriallisia tekstejä: Heikel näyttäytyy näissä keskusteluissa kansatieteen pioneerina, mutta myös arkeologian ja museoalan toimijana, joten hänen asemansa perinnetieteissä ei ole yksioikoinen. Reinholm oli ennen kaikkea piirtäjä, mutta hänen myötään taidemaailman konteksti tulee esiin perinteentutkimuksen yhteydessä. Tutkimuksen avustajana hän on jäänyt vähemmälle huomiolle. Enäjärvi-Haavio tuodaan esiin oppihistori-

\footnotetext{
${ }^{4}$ Tutkimuksen vastaanotto on huomioitu perinnetieteellisten tutkimusten lisäksi myös elämäkerrallisissa teoksissa (ks. Eskola 2003, 269-270; Sievänen-Allen 1993, 350-352).

${ }^{5}$ Maalausten ja kalevalaisen runon välisistä suhteista oli toki keskusteltu aiemmin jo 1800luvun puolella, kuten mm. Sihvo $(2003,230)$ muistuttaa taiteilijoiden Ekmanin ja Sjöstrandin teosten osalta.
} 
oissa esimerkiksi runojen esitysten ja leikin tutkijana. Hänen yhteydessään on käsitelty lisäksi tutkijoiden sukupuoleen liittyviä kysymyksiä. Piirroksia ei kuitenkaan nosteta esiin, vaikka molemmat niitä käyttivät. Osaltaan tämä kertonee perinnetieteellisen keskustelukulttuurin tekstuaalisesta orientaatiosta.

\section{PiIRrosten JA tekstin SUHDE HEIKELIN JA ENÄJÄRVi-HaAvion TUTKIMUKSISSA}

Yhtenä esimerkkinä kuvan ja tekstin suhteesta tarkastelen Reinholmin piirrosta eteläkarjalaisesta uunista ja sen ympäristöstä tuvassa (ks. kuva 1 , vasen kuva ja kuva 2).

\section{Kuva 1}

16

ihmeellisyys herättivät hänen lapsissaan ikuista ihastusta (1: $39-44 ; 50: 605-607$ )

Kiuas (kiukaa) 1. uuni rakennetaan Etelä-Karjalan tupaan 1. pirttiin hirsistä kokoonpannulle lavalle (kuvassa $13 \mathrm{~A}$. c), jotenka kivinen osa ei milloinkaan ulotu maahan asti, vaan sen alle jää melkoinen tyhjä tila, joka usein jätetään kissojen ja kanojen valtaan; ne siihen pyrkivät kissareiän kautta. Mutta tavallisesti tämä tila kuitenkin järjestetään pienersi komeron tapaiseksi suojaksi l. karsinalsi, joka lisäksi varus-

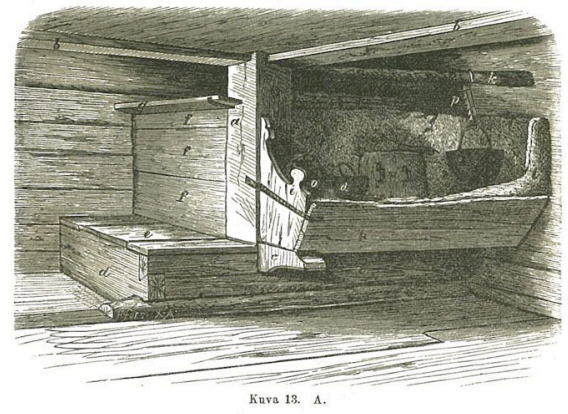

tetaan lantaisilla pykälillä 1 . hyllyillä. Sekä sillan alle että karsinaan käydään nykyään samoja suuren laatikon tapaisessa liolpitsassa (d) (голбеція) olevia portaita myöten ja tämän kolpitsan kansi $(e)$ on pidettävä uuninpenkkinä (pankkona). Toisinaan kolpitsa kumminkin Laatokankin seuduilla tykkänään puuttun, samoinkuin pankkokin (vrt. kuva B). Uunin kolkassa on patsas (a), josta lähtee kaksi ortta $(b)$, yksi kumpaiseenkin vastaiseen seinään. Patsassa nähdü̈̈ usein pieniä koloja l. pesurkkia (ven.), joissa kapineita pide-

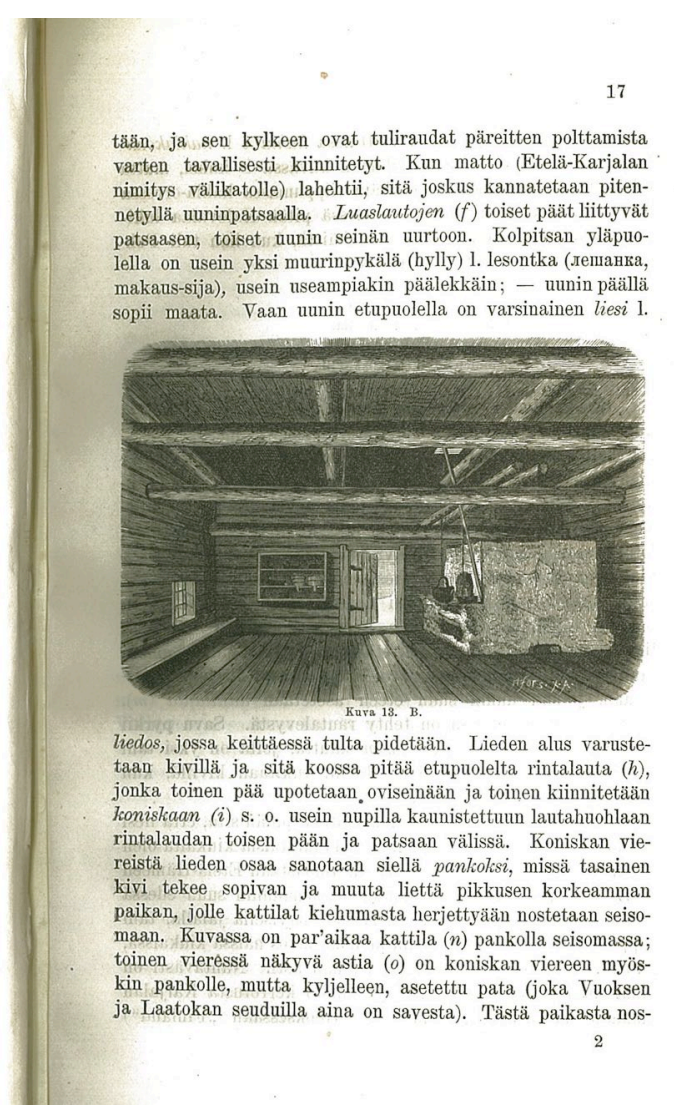

A. Reinholmin piirroksia ja A. O. Heikelin tekstiä teoksessa Kansatieteellinen sanasto (Heikel 1885, SKS).

Alkuperäinen piirros on tehty lyijykynällä, kun taas julkaisun piirros on tehty painoteknisistäkin syistä musteella. Piirros on osittainen, koska uunia ei ole esitetty jokaista yksityiskohtaa esiin tuoden, eikä hirsiseinää jokaista puunsyytä erotellen. Reinholmin on täytynyt päättää uunin ja hirsiseinän, kuten jokaisen tekemänsä piirroksen kohdalla, se tarkkuus, 
jolla yksityiskohdat piirretään. Kategorisointien analyysin yhteydessä ilmeni, että taiteeseen liitettiin usein vapauden kategoriapiirre. Piirroksen osittaisuus viittaa Reinholmin esimerkissä siihen, että piirroksissa on "vapauksia" yleisemminkin, ei vain taidepiirtämisen ominaisuutena, kuten Heikelin ja Reinholmin Karjalan matkan ohjeistuksessa oli.

Uunipiirroksen eri versioissa tarkkuus vaihtelee hieman osin siksi, että piirroksia on myöhemmin työstetty esimerkiksi julkaisujen painattamista varten (jäsenten metodi). Jälkikäteen ei voida tietää, kuinka paljon Heikel ja Reinholm ovat piirrosten tarkkuudesta keskustelleet. Boreniuksen matkaohjeessa tosin esineiden koon, materiaalien ja nimitysten lisäksi yksityiskohtaisuuttakin painotetaan: "[...] on tarkoin ja huolellisesti kuvattava kaikki esineet, jotka muinaisrunoissa mainitaan [...]" (SKS:n Keskustelemukset 1881，420; kursivoinnit alkuperäisessä). Heikelin $(1881,1)$ Uuteen Suomettareen kansatieteellistä keruuta varten laatima ohje on kiinnostava, koska siinä hän puuttuu myös kansatieteellisiin piirroksiin: Hänen mukaansa olisi tehtävä niin perspektiivikuvia kuin ääriviiva-, poikkileikkaus- ja pohjapiirroksia. Lisäksi tulisi kiinnittää huomiota kuvattavien kohteiden osiin, koristeisiin sekä väriin. (Mts.) Tarkkuus jää kuitenkin ohjeessa epämääräiseksi piirtämisen käytännön kannalta. Ohjeethan eivät kerro, kuinka tarkasti esimerkiksi lohkeamat, puunsyyt, oksanreiät ja muut yksityiskohdat tulisi esittää. Valinta jää piirtäjälle. Voidaan otaksua, että tuon ajan taiteilijoilta on saatettu odottaa realistisen kuvaamisen osaamista ja sen myötä jonkinlaista tarkkuutta. Jos näin olisi, tarkkuuden kriteerit olisivat lähtöisin taiteilijan ammattitaidon myötä taiteen piiristä ennemminkin kuin ohjeistetusti tutkimuksen alalta. Tirrasen (1960, 70-71) huomio siitä, että ohjeet olisivat rajoittaneet enemmänkin "[...] piirtäjän taiteellista vapautta [...]" voitaisiin tulkita viittaavan siis piirrosten aihevalintoihin.

Kun Reinholmin piirrosta katsotaan Kansatieteellisen sanaston tekstin yhteydessä, uunipiirrokseen liittyvä Heikelin teksti ankkuroi merkityksiä ja ohjaa tulkitsemaan kuvaa mielekkäästi. Niinpä piirroksen voi tulkita esittävän uunia eikä esimerkiksi kivikasaa tai hautakammiota. Piirrosten ja tekstin sijoittelu vaihtelevat kuitenkin Heikelin julkaisuissa uunikuvauksen osalta. Heikelin väitöskirjassa $(1887,225-226)$ on sama uunin ja tuvan muodostama kuvapari kuin Kansatieteellisessä sanastossakin. Väitöskirjassa käsitellään suomalaisten rakennusten lisäksi laajasti esimerkiksi marien (tšeremissien), mordvalaisten, venäläisten ja virolaisten rakennuksia. Tutkimuksen näkökulma on vertaileva, ja näin ollen paikkakuntien rakennustyyppejä käsitellään limittäin. Asiakokonaisuudet muodostavat toisiaan seuraavan jatkumon, jota väliotsikoinnit rytmittävät. Multimodaalisen rajauksen, miksei huomioarvonkin, voi ajatella viittaavan myös tällaisiin rytmityksiin: otsikoinneilla ja väleillä rajataan käsiteltyjä aiheita 
tekstissä, joten niillä painotetaan asiakokonaisuuksia. Heikelin väitöskirjassa piirrokset on sijoitettu useimmiten asiayhteyksiinsä, mutta aina ne eivät ole sopineet aivan tekstissä käsitellyn aiheen yhteyteen, siis esimerkiksi samalle aukeamalle. Kalevalassa (1887) piirrokset on sijoitettu liitteeseen kirjan loppuun. Tällaisilla seikoilla on vaikutusta siihen, miten tekstit ja piirrokset kytkeytyvät toisiinsa. Kalevalassa tekstin ja kuvan voi yhdistää nimenomaan piirrosten numeroinnin avulla. Heikelin väitöskirjassa piirrokset jäisivät irrallisiksi ilman kuvatekstejä ja niiden ankkurointeja. Aikoinaan Theodor Schvindt kritisoikin väitöskirjaa muun muassa epäselvyydestä sekä joistakin piirrosten ja tekstin epäjohdonmukaisuuksista (1888a, 459-460, 462; myös Niiranen 1987, 92-93).

Heikelin Kansatieteellisen sanaston uunikuvauksessa piirustuksiin viitataan tekstissä kuvien numeroiden lisäksi myös kuvan yksityiskohtien tunnisteiden ( $a, b, c$ jne.) avulla (ks. kuva 1 ):

Kiuas (kiukaa) I. uuni rakennetaan Etelä-Karjalan tupaan I. pirttiin hirsistä kokoonpannulle lavalle (kuvassa 13 A. c), jotenka kivinen osa ei milloinkaan ulotu maahan asti [...] (Heikel 1885, 16; korostukset alkuperäisessä).

Olennaista on viittaus piirroksen yksityiskohtaan ilmauksessa "kuvassa 13 A. C". Sen voi ymmärtää ankkurointina, jolloin mielekäs tulkintakehys olisi eteläkarjalainen tupa. Toisaalta viittaamalla tunnisteeseen "c" (jäsenten metodi), joka löytyy myös piirroksesta, Heikel painottaa yksityiskohtaisempaa luentaa uunista, sen sijainnista ja rakenteesta. Niinpä uunin yksityiskohdat ovat tässä huomionarvoisin asia. Heikelin kuvaus havainnollistaa yhtäältä uunin rakennetta ja osia kansatieteelliseltä kannalta. Toisaalta hiukan myöhemmin Heikelin tekstissä selvitetään kansanrunoudentutkimuksellisesti Kalevalan erikoisia ilmauksia ja sanoja, kuten "luaslautoja", "kolpitsoja" ja muita runoissa esiintyviä uunin osien nimityksiä (mts. 16-17; ks. Kalevala 1887, 158). Tietoarvon kannalta ajateltuna nämä ilmaukset ovat uutta, runoihin viittaavaa tietoa suhteessa piirrokseen. Huomioarvon näkökulmasta Heikelin runojen luenta on kuitenkin luonteeltaan teknistä nimenomaan uunin teknisiin ja rakenteellisiin yksityiskohtiin syventyessään. ${ }^{6}$ Huomioarvon ja tietoarvon tarkastelu tuo tässä kiinnostavasti esiin kansatieteellisen ja kansanrunoudentutkimuksellisen otteen vuorovaikutuksen.

\footnotetext{
6 Myös esimerkiksi kansanrunoudentutkija Oskar Relanderin (1894) runojen kielikuvia käsittelevässä tutkimuksessa ote runoihin on tekninen. Relanderillakin runojen maailman yksityiskohtia, kasveja, esineitä ja muita asioita eritellään luokitellen ja yksityiskohtaisesti.
} 


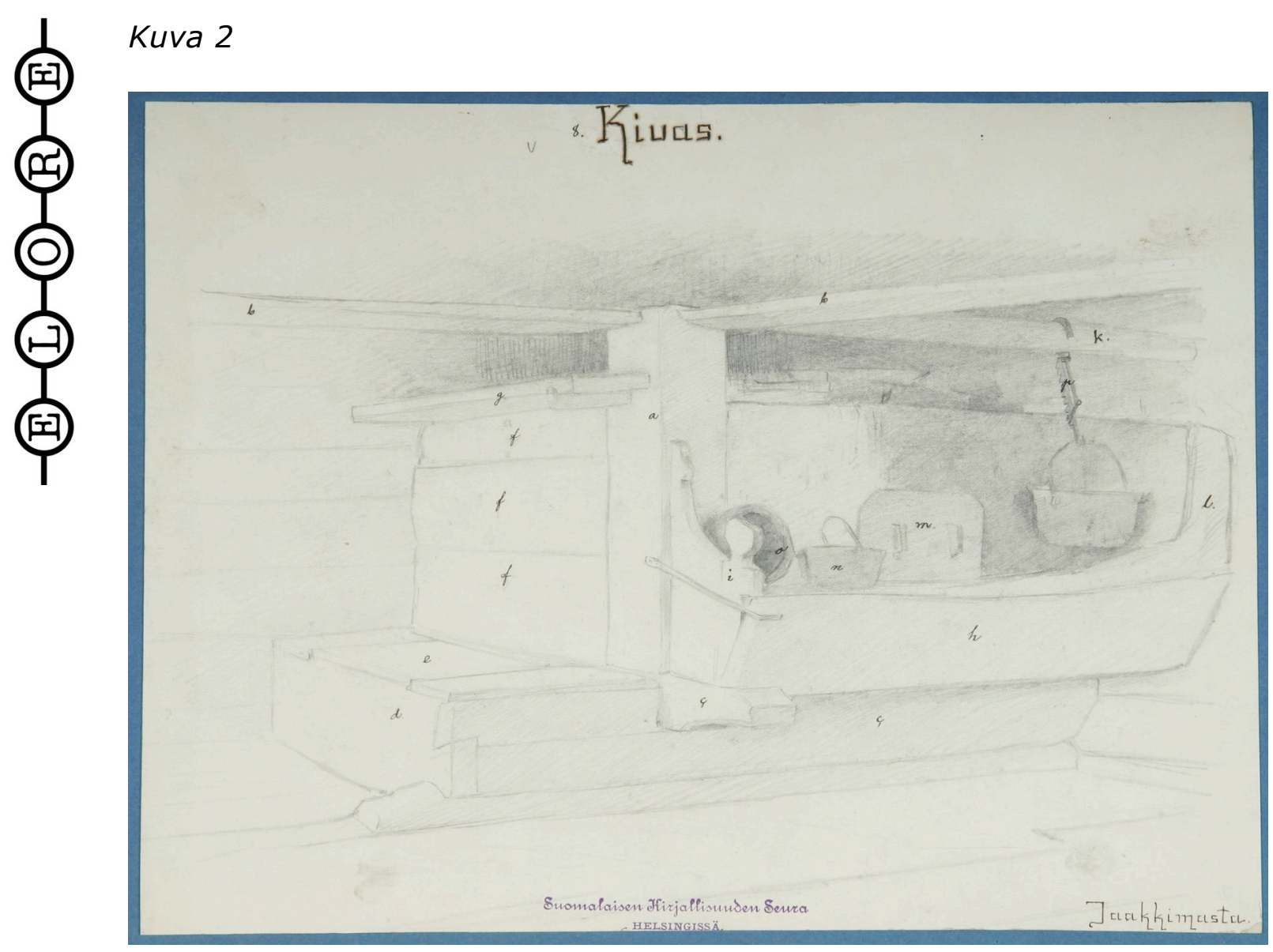

Agathon Reinholmin lyijykynäpiirros uunista. Kuva: SKS KRAK 1880:E 85:8.

Reinholmin alkuperäisistä piirroksista uunin kuvauksen kannalta keskeisin on "Kiuas" (ks. kuva 2). Siinä uuni on esitetty yksityiskohtaisesti ja selitteiden ( $a, b, c$ jne.) kera. Piirroksen rajaus ja asetelma on likipitäen sama alkuperäisessä ja julkaisujen versioissa. Selitteet löytyvät myös Heikelin alkuperäisistä käsikirjoituksista (SKS Jpa Heikel 84:165 ja 78:1415). Eteläkarjalaisen uunin kuvaus on saanut siis perusmuotonsa käsikirjoitustasolla. Huomioarvon kannalta olennaista on, että painotuksetkin erottuvat jo käsinkirjoitetusta tekstistä, koska keskeisiä käsitteitä on alleviivattu molemmissa käsikirjoituksen versioissa. Jäsenten metodit ilmenevät tässä siinä, että piirroksiin ja tekstiin on liitetty merkintöjä. Tutkimuksen käytännöt tulevat näkyviksi näissä merkinnöissä, mikä näkyy hyvin käsikirjoitusversioita tarkastelemalla: niissähän on paljon kaikenlaisia muistiinpanoja ja korjauksia ja niin edelleen. Julkaisun tekstissä alleviivauksen sijaan käytetään korostuskeinona kursivointia. Painotukset vaihtelevat hieman sisällöllisestikin julkaisujen kesken. Kansatieteellisessä sanastossa (Heikel 1885, 16-22) uunia on käsitelty laajasti: Ensimmäisenä luetellaan uunin osien nimitykset ja tunnisteet ( $a, b, c$ jne.) kuten käsikirjoituksessa. Tekstin lopussa on useita poimintoja Kalevalan runojen uuniin liittyvistä sanoista. Näihin liittyen piirroksien avulla siis selitetään 
runon ilmaisuja, ja tässä mielessä uunin kuvaus kytkeytyy erityisesti kansanrunoudentutkimukseen. Myös Kalevalan (1887) liitteessä uunin kuvauksella selitetään runojen ilmaisuja. Heikel (mts. 473) luo siinä lisäksi tekstien välisiä viittaussuhteita viittaamalla esimerkiksi Kansatieteelliseen sanastoon.

Heikelin väitöskirjassa taas on kansatieteellisempi ote. Siinä uunin kuvauksessa piirroksissa ja tekstissä ei ole selitteitä ( $a, b, c$ jne.), joten painotuksetkin ovat erilaisia. Uunin kuvaus kontekstualisoituu väitöskirjassa yleisemmin osaksi suomalaisia rakennusmuotoja käsittelevää jaksoa. Väitöskirjan kokonaisuuden kautta se taas asemoituu esimerkiksi evolutionistiseen ja typologisoivaan rakennustutkimukselliseen kehykseen (ks. Niiranen 1987, 79-97). Väitöskirjan aihepiiri on kokonaisuudessaan laaja, mistä Schvindt (1888a, 459) väitöskirjaa kritisoi.

Yhteistä Heikelin tutkimuksille sekä Enäjärvi-Haavion (1949) Pankame käsi kätehen -tutkimukselle on, että molemmat käyttivät erilaisia piirroksia tutkimuksissaan. G. Acerbin ja A. F. Skjöldebrandin runonlaulukuvausten käsittely muodostaa Enäjärvi-Haavion teoksessa (1949, 56-72) monien tekstien ja kuvien verkoston. Huomioarvon kannalta olennaista on, ettei Enäjärvi-Haavio käytä piirrosten yhteydessä suoraan kuviin viittaavia selitteitä kuten Heikel käytti. Ankkurointi tapahtuu kuvatekstein, mutta löyhästi. Piirrosten yksityiskohtien erot ovat ratkaisevassa asemassa sekä argumentoinnissa yleensä että tekstin ja piirrosten kytkemisessä yhteen. Tätä havainnollistaa esimerkiksi katkelma, jossa Enäjärvi-Haavio luonnehtii Acerbin piirrosta: "Hän koristeli uunin, hän lisäsi kuvaan kolmikerroksisen sängyn, joka kiinnosti häntä, ja laulajain ja soittajan ryhmityksen hän esitteli sellaisena kun hän sen käsitti Porthanin teoksen mukaan" (mts. 63). Ilmaukset "koristeli" ja "lisäsi" tuovat esiin piirtämiseen liittyviä valintoja. Tekstikatkelma kuvaa siis sitä, miten Acerbi on Enäjärvi-Haavion mukaan tehnyt kuvaa valikoiden. Valikoivuuteen viittaavat ilmaukset kuten "kiinnosti" ja "käsitti". Näitä seikkoja erittelemällä Enäjärvi-Haavio havainnollistaa miten piirrosten osittaisuus muodostuu.

Tekstikatkelma kertoo siitä, miten interiöörin kuvauksen ristiriitaisuudet toimivat Enäjärvi-Haavion mukaan todisteena runonlaulukuvausten epäluotettavuudesta. Keskittyessään piirrosten esineympäristön yksityiskohtiin Enäjärvi-Haavio operoi kansatieteellisillä kysymyksenasetteluilla. Perusteluna ja vertailupintana hänellä on myös kirjallisia lähteitä ja varhaisempia tutkimuksia (Enäjärvi-Haavio 1949, 56-72). Risto Turunen (1995, 92) onkin kiinnittänyt huomiota Enäjärvi-Haavion kirjallisiin aineistoihin sekä lähdekriittisen otteeseen Pankame käsi kätehen tutkimusta tarkastellessaan. Piirrosten yksityiskohtien kannalta kiinnostavaa on se, miten Enäjärvi-Haavio $(1949,58)$ tukeutuu Kustaa Vilkunan arvioon Skjöldebrandin piirroksen vääränlaisesta kattoluukusta ja hieman 
myöhemmin Tyyni Vahterin näkemykseen Skjöldebrandin ja Acerbin piirroksessa esitettyjen asujen "epätodenmukaisuudesta" (mts. 63). Huomioarvon kannalta olennaista on siis piirrosten kansatieteellisen epäjohdonmukaisuuden esiin tuominen. Lisäksi esimerkki osoittaa, että Enäjärvi-Haavio hyödynsi jäsenten metodina lähdekritiikin ohella taitavasti myös sosiaalisia verkostojaan argumentoinnissa: piirroksista on keskusteltu yhdessä, joten ne ovat olleet yksi väylä perinnetieteilijöiden ja kansatieteilijöiden vuorovaikutuksen ylläpitämisessä.

Piirrosten roolin merkittävyyttä Enäjärvi-Haavion argumentoinnissa havainnollistaa myös muistiinpano, jossa hän pohtii, että Skjöldebrandin ja Acerbin piirrokset olisi hyvä saada samalle aukeamalle, jotta niitä voisi tarkastella yhtä aikaa (SKS KIA Enäjärvi-Haavio I. 5.). Pankame käsi kätehen -tutkimuksessa (1949, 60-61) piirrokset ovat lopulta samalla aukeamalla. Multimodaalisen tietoarvon kannalta tämä on kiinnostava pohdinta, koska piirrosten sijoittaminen samalle aukeamalle korostaa annetun ja uuden tiedon jännitettä. Skjöldebrandin (annettu) ja Acerbin (uusi) piirrokset kommentoivat toisiaan selkeästi vierekkäin asetettuna. Olennaista asetelmassa on tiedon välittymisen kannalta se, että Acerbin piirros perustui aiemmin julkaistuun Skjöldebrandin kuvaan.

Enäjärvi-Haavio (mts. 73-133) käsittelee tutkimuksessaan lisäksi useita Skjöldebrandin ja Acerbin esittelemää runonlaulutapaa myöhemmin toistavia kuvallisia esityksiä, joista on muodostunut eräänlainen kuvallinen jatkumo. Piirrosten yksityiskohtia erittelemällä Enäjärvi-Haavio ilmentää kuitenkin, että jatkumoissa on epäjohdonmukaisuuksia: kattoluukut ovat vääränlaisia, asut omituisia ja niin edelleen. Piirtäjät ovat siis käyttäneet vapauttaan reilusti. Enäjärvi-Haavion mukaan piirrosten tekijät eivät välttämättä ole todistaneetkaan piirrosten kaltaista runonesitystilannetta (mts. 63). Analyysinsa johtopäätöksenä hän toteaakin: "Alkuperäisen todistuskappaleen arvo heidän kertomuksiltaan ja kuviltaan kuitenkin puuttuu" (mts. 72).

Kuva 3

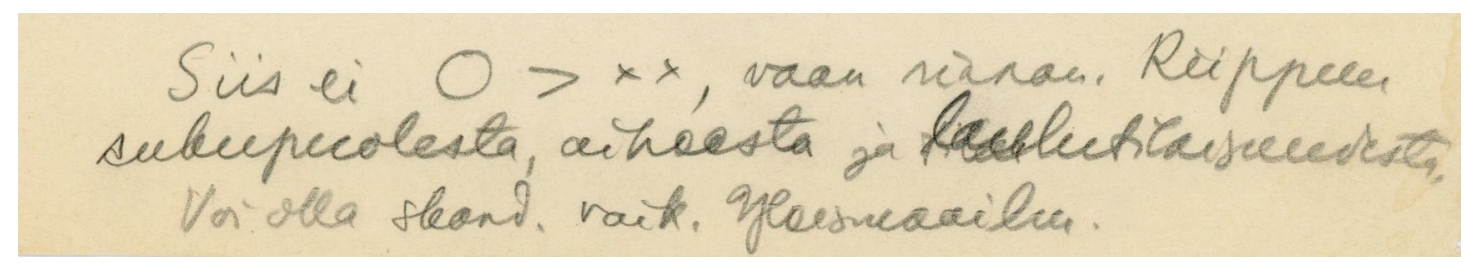

Enäjärvi-Haavion piirrosmerkintöjä tekstin lomassa. Yksityiskohta muistiinpanosivulta. Kuva: SKS KIA Enäjärvi-Haavio I. 4. 


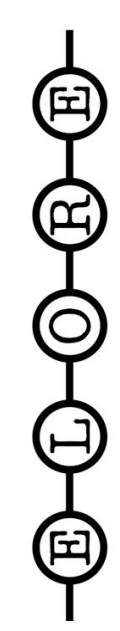

Seuraavaksi siirryn tarkastelussani hieman erityyppisten piirrosten pariin. Tutustuessani Enäjärvi-Haavion käsikirjoituksiin arkistossa aloin kiinnittää huomiota dokumenteissa usein toistuviin erilaisiin kaaviopiirroksiin (ks. kuvat 3 ja 4) (SKS KIA Enäjärvi-Haavio I. 4. ja I. 5). Kuvassa 3. on yksityiskohta muistiinpanosta ja sen kaaviopiirroksista.

Ilmaus "Siis ei $O>x x$, vaan rinnan." on hauska esimerkki kuvien ja tekstien suhteen monimuotoisuudesta ja siitä, ettei kuvan ja sanan suhdetta tulisi yksinkertaistaa. Kirjoitusmerkkejä käytetään tässä kuvaavina symboleina tekstin keskellä (jäsenten metodi). Esimerkin voinee tulkita tarkoittavan, ettei piirilaulusta (O) siirrytty (>) kaksinlauluun (xx) vaan nämä olleet olemassa rinnakkain. Enäjärvi-Haavion tutkimuksen kokonaisuus ohjaa ajattelemaan, että kuviot liittyvät runojen esitystapoihin. Kaavio on huomioarvon kannalta painokas, koska kuviot ovat tekstin kaltaisia, mutta silti ne erottuvat hyvin tekstistä, koska ne eivät kuitenkaan ole varsinaista tekstiä. Tietoarvon kannalta olennaista on, että piirroskaaviot seuraavat tekstin suuntaa vasemmalta oikealle. Kuviossa-

\section{Kuva 4}

And, Buoke. 1936, ss.65-.

Siteraa

Porthaw tow

Tengotion a

Acertion 0

Linnot taulutope- $2 . \because$

Melka

Barenies

Sanals

Sack. Josto refs.

verius a rep

Launis tansoit

Lanlut

Krohn

alnune

Lacenis

(Vacisañen)

Enäjärvi-Haavion muistiinpanosivu. Kuva: SKS KIA Enäjärvi-Haavio I. 4. han piirilaulusta (annettu) siirrytään ( $>$ ) kaksinlauluun (uusi tieto). Kaaviokuvio rajautuu tekstin yhteyteen, koska piirros pysyttelee tekstin rivillä. Kaaviot ovat objektiivisia kuvia, koska "piiritanssijat" (O) esitetään ylhäältä päin. Yleisesti arvioituna näyttäisi siltä, että kaaviopiirrokset ovat toimineet Enäjärvi-Haaviolla tutkimusongelman kokonaisuuden työstämisen välineenä tutkimusprosessin aikana sekä muistiinpanojen työkaluna siinä missä erilaiset sanalliset listaukset ja lyhenteetkin.

Kuvan 4 esimerkki havainnollistaa joitain ongelmia, joita esitysten pelkistyneisyys voi tuottaa.

Onko kuvan 4 muistiinpanossa tiiviisti esitettynä koko Enäjärvi-Haavion tutkimuksen aihepiiri? Pohdittuani aikani muistiinpanoa tarkistin Pankame käsi kätehen -teoksen alaviitteissä mainittuja lähteitä ja löysin viittauksia Otto Anderssonin (1936) artikkeliin Budkavlen julkaisussa. Nimien järjestys muistiinpanossa näyttäisi täsmäävän Anderssonin artikkelin viittausten järjestyksen 
kanssa, mihin muistiinpanon ilmaus "Siteeraa:" viitannee. Listausta voisi pitää eräänlaisena multimodaalisena rajauksena, koska näiden nimenomaisten henkilöiden mainitseminen lapussa rajaa aiheen Anderssonin artikkeliin. Otaksun, että lappunen on Enäjärvi-Haavion muistiinpano tästä artikkelista. Piirrosten kannalta olennaista on, että kaaviopiirroksilla Enäjärvi-Haavio kykenee tuomaan muistiinpanoon nimien lisäksi tietoja myös esitystavoista. Esimerkiksi "Porthan" voidaan ajatella annettuna ja sen oikealla puolella oleva piirros uutena tiedollisena elementtinä, sillä piirroskuvio antaa uutta tietoa Porthanin laulutapakäsityksistä. Ilman kaaviokuvia muistiinpano olisi vain lista niistä henkilöistä, joihin Andersson artikkelissaan viittaa. Niinpä piirroskuviot täydentävät muistiinpanoa ja lisäävät muistiinpanon tietoarvoa.

Luulin aluksi, että kuvan 4 muistiinpanossa oli kyse Enäjärvi-Haavion oman tutkimuksen rakenteen pohtimisesta. Pelkistetyt graafiset esitykset voivat siis olla käytännöllisiä apuvälineitä tiedon käsittelyssä, mutta ulkopuoliselle tulkitsijalle ne voivat olla haasteellisia. Edellä käsitellyt

\section{Kuva 5}

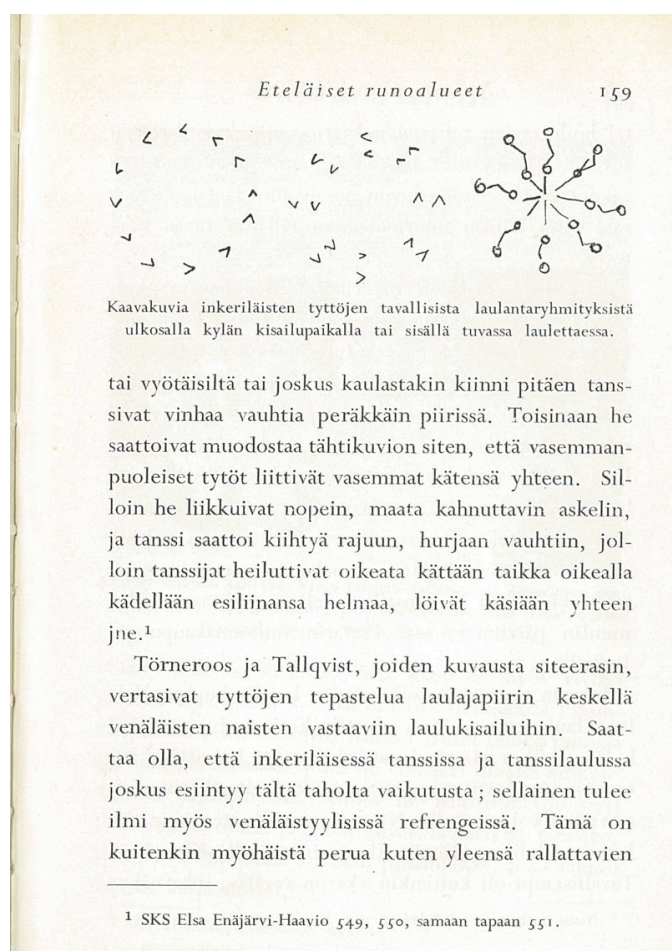

Enäjärvi-Haavion kaaviopiirroksia runolaulun ryhmityksistä teoksessa Pankame käsi kätehen (EnäjärviHaavio 1949, WSOY). esimerkit havainnollistavat kuitenkin, miten monipuolisesti Enäjärvi-Haavio on käyttänyt kaaviopiirroksia tutkimusta tehdessään: piirroksia on pohdittu ja työstetty. Enäjärvi-Haavion omat piirrokset ovat tärkeitä tutkimuksen kannalta siitä huolimatta, että tutkimusjulkaisussa (ks. kuva 5) niitä on vain kolme kappaletta. Teoksessa olevilla kaaviopiirroksilla on suuri huomioarvo, koska ne ovat ainoat piirretyt kaaviokuvat tutkimuksessa. Mitä kaaviolla on sitten haluttu nostaa esiin?

Piirrokset tulevat esiin teoksessa käsiteltäessä runonlaulajien ryhmitysten eroja, missä yhteydessä myös EnäjärviHaavion omat kenttähavainnot vuoden 1936 matkalta ovat keskeisessä osassa.

Puhtaaksikirjoitetuissa arkistodokumenteissa on paikoin mukana samanlaisia kaaviopiirroksia (ks. SKS Jpa EnäjärviHaavio). ${ }^{7}$ Enäjärvi-Haavion (1949, 159) kuvatekstin rooli piirrosten merkitysten ankkuroijana on suuri: "Kaavakuvia

\footnotetext{
7 Arosen $(2014,11)$ artikkelissa Ullo Toomin muistiinpanoissa olevat piirrokset ovat samankaltaisia kuin Enäjärvi-Haaviolla.
} 
inkeriläisten tyttöjen tavallisista laulantaryhmityksistä ulkosalla kylän kisailupaikalla tai sisällä tuvassa laulettaessa". Enäjärvi-Haavio ei ole käyttänyt kuvatekstin lisäksi muita tarkentavia selitteitä ( $a, b$, c tms.), jotka loisivat multimodaalisia painotuksia. Enäjärvi-Haavio ei myöskään selitä tekstissään yksityiskohtaisesti, mitä piirrosten merkit tarkoittavat. Kuvatekstin ja muun tekstin myötä miellämme nuolikuviot ( $>$ ) tanssijoiksi (vrt. kuva 3). Erityisesti ilmaus "inkeriläiset tytöt" kytkee kuviot nimenomaan näihin sosiaalisiin kategorioihin. Kyse on sekä topologisista että objektiivisista kuvista, koska piirroksissa esitetään "tanssijoita" tai tanssiryhmityksiä, siis tanssijoiden suhteita ja liikeratoja ylhäältä päin kuvattuna. Yksittäisen nuolikuvion edustaman henkilön henkilöllisyyden tai ominaisuuksien sijaan piirroksessa ollaan kiinnostuneempia tapahtumasta kokonaisuutena. Myös erilaisten tanssiryhmitysten vertailu on tehty mahdollisimman helpoksi.

Enäjärvi-Haavion tutkimuksesta poimitut esimerkit kuvaavat, miten perinteentutkimuksen näkökulmat voivat konkretisoitua tutkimuksissa. Hänen esitystutkimuksellinen näkökulmansa konkretisoituu edellä käsitellyssä tutkimuksen kohdassa piirroksien avulla. Heikelilläkin (ks. esim. 1887, 229, 230, 231, 235) on väitöskirjassaan paljon muun muassa rakennusten pohjapiirroksia, joiden voi ajatella konkretisoivan rakennusmuotojen vertailun näkökulmaa. Piirrosten objektiivisia tai topologisia piirteitä tarkastelemalla voikin havainnollistaa sitä, miten tutkijat rajaavat tarkastelemaansa aihetta. Kaaviokuvat ovat kuitenkin vain yhdenlainen piirrostyyppi, aivan kuten Reinholmin esittävät piirrokset. Esimerkeilläni olenkin pyrkinyt tuomaan esiin sitä, että tutkijoilla on käytössään monia erilaisia jäsenten metodeja piirrosten hyödyntämisessä, olipa kyseessä runonlaulu tai esineet, tanssiryhmitys tai pihapiirin talojen ryhmitys. Piirrokset eivät ole välttämättä staattista kuvitusta, vaan niistä on nostettu esiin erilaisia asioita argumentoinnin tueksi eri yhteyksissä.

\section{JOHTOPÄÄTÖKSIÄ PIIRROSTEN ASEMASTA SEKÄ PIIRUSTUSTUTKIMUKSEN MAHDOLLISUUKSISTA PERINNETIETEISSÄ}

Artikkelini metodiset valinnat korostavat tarkastelemieni tekstien ja piirrosten yksityiskohtaisuutta. Multimodaalista tutkimusta voidaankin kritisoida "impressionistisuudesta" ja hienojakoisuudesta (Jewitt 2009a, 26-27). Samansuuntaista kritiikkiä on esitetty etnometodologiastakin (ks. esim. Knuuttila 1994, 73). Detaljeihin syventyminen on tuonut kuitenkin esiin, miten yksityiskohtaisuudesta huolimatta piirroksilla on ollut laajempaakin merkitystä: Reinholmin piirroksilla ja Heikelin selostuksilla on tehty Kalevalaa helpommin lähestyttäväksi. Enäjärvi-Haavio taas kuvasi runonlauluun liittyviä kuvallisia jatkumoita. Heikelin uunikuvauksen ja Enäjärvi- 
Haavion runonlaulutapojen omat kuvaukset voi paikantaa yhtä hyvin kansatieteen kuin folkloristiikankin piiriin. Vasta julkaisujen kehys suuntaa ne tarkemmin jompaankumpaan. Julkaisujen merkitys onkin eittämättä suuri perinnetieteellisiä piirroksia ja piirtäjiä pohdittaessa.

Yksi tavoitteeni tässä artikkelissa on ollut tarkastella perinnetieteellisten piirrosten tiedollista asemaa ja konteksteja. Kategorisointien yksityiskohtia analysoimalla on nähtävissä, millaisia moninaisia rooleja tutkijoilla ja piirtäjillä sekä piirroksilla on ollut alalla. Moniulotteisuuden rinnalla on hahmotettavissa myös asemointien toistuvuuksia: oppialan tutkimuspiirin avartuminen ja tutkimusotteen tieteellinen luonne tulevat esiin niin Heikelin kuin Enäjärvi-Haavionkin yhteydessä, joten kyseiset tutkijat näyttäytyvät alansa edelläkävijöinä. Oppihistorioissa erilaisia tutkimuksellisia rooleja on sekä vahvistettu että purettu, joten perinnetieteet hahmottuvat vaihtelevana kontekstina piirroksille. Oppihistorian painotuksista johtuen piirtäminen näyttäytyy kuitenkin usein tutkimusta avustavana toimintana tai muiden kuin perinteentutkijoiden harjoittamana toimintana, joten aivan oppihistorioiden ytimessä piirrokset eivät ole sijainneet.

Tarkastelin edellä piirrosten kytkeytymistä tekstiin osana tutkimusten argumentointia, en niinkään piirroksia itsenäisinä teoksina. Kuvan ja tekstin ankkurointi osoittautui yleisellä tasolla liikkuvaksi lähestymistavaksi, joten nostin esiin multimodaalisen tutkimuksen käsitteitä syventyäkseni tarkemmin piirrosten ja tekstin suhteisiin. Piirrosten huomioarvon yhteydessä korostui piirrosten yksityiskohtaisuus niin Heikelin kuin Enäjärvi-Haavionkin kohdalla. Piirrokset ovat valikoivia, mutta tästä huolimatta niillä on haluttu suunnata lukijan huomio ilmiöiden yksityiskohtiin: Heikelillä uunin osiin, Enäjärvi-Haaviolla esitystapojen koreografioihin. Tietoarvoa tutkimalla havainnollistui, miten piirrosten avulla tuotetaan uutta tietoa ja täydennetään tekstiä. Topologisten ja objektiivisten kuvien kautta taas nähtiin, miten piirroksissa voidaan korostaa asioiden suhteiden esittämistä: esittämällä tanssijat kaavioissa ylhäältä päin EnäjärviHaavio kytki itsensä ja lukijan piirrosten avulla teoreettisempaan tarkastelutapaan. Samoin teki Heikel rakennusten pohjapiirroksia käsitellessään.

Luonnollisestikaan kaikki perinteentutkijat eivät ole piirtäjiä samassa mielessä kuin esimerkiksi Reinholm oli, mutta piirrosten käyttämiseen on ollut tutkimuksissa erilaisia väyliä ja jäsenten metodeja. Piirroksia onkin hyödynnetty monipuolisesti erityisesti näkökulmien konkretisoinnissa. Esimerkiksi asioiden suhteiden painottaminen oli yksityiskohtaisuuden ohella yksi keskeisistä piirrosten menetelmällisistä ulottuvuuksista. Piirrosten tiedollisen aseman kannalta kiinnostavaa tässä on, että piirrokset kytkeytyvät perinnetieteiden teoriapohjaisiin erityiskysymyksiin, kuten rakennustyyppien vertailuun, runokielen analyysiin tai esitystutkimukseen, mutta samalla piirrosten käyttö perustuu myös yleisiin piirrokselli- 
siin ilmaisukeinoihin, kuten pelkistämiseen tai piirrosten ja tekstin, siis tunnisteiden ( $a, b, c$ jne.) yhdistämiseen. Kuten edellä nähtiin, piirrosten "päälle" voi kirjoitella kaikenlaista samoin kuin kirjoitukseen voi lisätä piirroksia. Näitä tieteellisten ja arkisten jäsenten metodien kietoutumisia edellä oleva multimodaalinen analyysi havainnollistaa.

Metodisesta näkökulmasta katsottuna piirrokset eivät ole pelkästään tutkimusten kuvitusta. Käsittelemissäni esimerkeissä tutkimuskohteen konstruointi perustuu osin piirroksiin. Niinpä oppihistoriassa moneen kertaan puretut ja kootut käsitykset perinteestä sisältävät niin ikään piirroksiin tukeutuvia näkemyksiä, huolimatta siitä, ettei piirroksia ole välttämättä suoranaisesti käsitelty näissä keskusteluissa. Jatkumot eivät ole vain tekstuaalisia, vaikka esimerkiksi perinteen tekstuaalistaminen ajateltaisiinkin yhdeksi oppialan keskeisistä prosesseista (ks. Anttonen 2005, 54-57; Lehtipuro 1983, 209). Perinnetieteiden monet jännitteet koskevatkin myös alalla tehtyjä piirroksia. Esimerkiksi tutkimusten poliittiset ja ideologiset kytkennät ovat tietokäsitysten ja oppialan identiteetin kannalta paljon keskusteltu kysymys perinnetieteissä (esim. Vakimo 2008; Anttonen 2005; Knuuttila 1999; Sääskilahti 1997; Pöysä 1989; Wilson 1985). Tällaisissa keskusteluissa onkin yksi mahdollinen suunta tulevalle perinnetieteelliselle piirrosten tutkimukselle.

Piirrokset ovat osa perinteentutkimuksen käytäntöjä. Tähän viittaa artikkelin otsikon ajatus piirroksista tietona. Osa tutkimuskohteen konstruoinnin kytkennöistä on ilmeisempiä, osa hankalammin hahmotettavissa, koska tutkimuksen materiaaliset käytännöt ja aihepiiri voivat kietoutua toisiinsa niin monisyisesti. Siksi perinnetieteellisiin piirroksiin kannattaa kiinnittää huomiota niin oppihistorian kannalta kuin myös nykypäivän perinteentutkimuksessa. Ja myös siksi, että piirtämisen myötä ollaan lähellä tutkimuksen tekemisen käsityötä. 


\section{TUTKIMUSAINEISTOT}

\section{Arkistoaineistot}

Museovirasto (MV), Kansallismuseon Kansatieteellinen arkisto (KM:K).

- MV KM:K1012. A. O. Heikelin aineisto. (Käsikirjoituksia, muistiinpanoja, kirjeenvaihtoa ja muuta sekalaista materiaalia.)

Museovirasto (MV), Kuva-arkisto, Kansatieteen kuvakokoelmat (KK).

- MV KK1120:1-155. Reinholm, Agathon. (Piirroksia.)

Museovirasto (MV), Kulttuurien Museon arkisto (KMA).

- MV KMA. Heikel, Axel Olai. (Julkaisematonta sekalaista kuva-aineistoa. Mm. A. Reinholmin, S. von Bellin ja S. Jekimovin piirroksia.)

Suomalaisen Kirjallisuuden Seuran Joensuun perinnearkisto (SKS Jpa).

- SKS Jpa. Enäjärvi-Haavio, Elsa 404-916. 1936. Viron Inkeri. (Mikrofilmirulla no 50. Kansantietoutta Viron Inkeristä.)

- SKS Jpa. Heikel, Axel Olai 84:151-458. 1880. Etelä-Karjala. (Mikrofilmirulla no 605. Kansatieteellisiä tutkimuksia Karjalasta v. $1879^{8}$.)

- SKS Jpa. Heikel, Axel Olai 78:1-212. 1880. Etelä-Karjala. (Mikrofilmirulla no 603. Kansatieteellisiä tutkimuksia Karjalassa. (Alkup. Käsik.))

Suomalaisen Kirjallisuuden Seuran kansanrunousarkisto, kuvakokoelmat (SKS KRAK).

- SKS KRAK 1880:E 85:1-334. Reinholm, Agathon. Etelä-Karjala. (Piirroksia.) (Mikrofilmirulla no 605. Kansatieteellinen kuvasto II.)

- SKS KRAK 1880:E 85:8. Reinholm, Agathon. Etelä-Karjala. (Mikrofilmirulla no 605. Kansatieteellinen kuvasto II: "Kiuas. Jaakkimasta.")

Suomalaisen Kirjallisuuden Seuran kirjallisuusarkisto (SKS KIA).

- SKS KIA, Elsa Enäjärvi-Haavion arkisto. Pankame käsi kätehen. Käsikirjoituskokoelma I. 4. ja I. 5.

\footnotetext{
${ }^{8}$ Vuosiluku on alkuperäisessä virheellisesti. Pitäisi olla 1880.
} 


\section{Painetut aineistot}

Enäjärvi-Haavio, Elsa 1949: Pankame käsi kätehen. Suomalaisten kansanrunojen esittämistavoista. Porvoo: WSOY.

Heikel, Axel Olai 1881: Ohjeeksi kansatieteellisten aineitten kerääjille. Uusi Suometar 23.5.1881: 1.

Heikel, Axel Olai 1885: Kansatieteellinen sanasto kuvien kanssa. Vähäinen alku-koetus muutamien Kalevalassa mainittujen esineitten selittämiseksi. Helsinki: SKS.

Heikel, Axel Olai 1887: Rakennukset tš̌eremisseillä, mordvalaisilla, virolaisilla ja suomalaisilla. Akateeminen väitöskirja. Helsinki: SKS.

Heikel, Axel Olai 1888b: Vastaus Hra Th. S:lle. (Liite Valvojan yhdenteentoista vihkoon.) - Valvoja 8(11): 1-9.

Heikel, Axel Olai 1920: Kansatieteellisten tutkimusmatkojeni alkuajoista. Agathon Reinholm in memoriam. - Juhlajulkaisu Ylioppilastalon 50vuotisjuhlaan. Helsinki. 66-69.

Kalewala. Kolmas helppohintainen, selityksillä ja kuvilla warustettu painos. 1887. Helsinki: SKS.

Kalevala. II. Selityksiä. 1895. Helsinki: SKS.

Niemi, A. R. (toim.) 1910: Kalevalan selityksiä. Helsinki: SKS.

SKS:n keskustelemukset 1881: Suomalaisen Kirjallisuuden Seuran keskustelemukset vv. 1879-1881. - Suomi. Kirjoituksia isänmaallisista aineista. 1881. II Jakso. 14. Osa. Helsinki: SKS. 297505.

SKS:n keskustelemukset 1883: Suomalaisen Kirjallisuuden Seuran keskustelemukset vv. 1881-1883. - Suomi. Kirjoituksia isänmaallisista aineista. 1883. II Jakso. 16. Osa. Helsinki: SKS. 351555.

SKS:n keskustelemukset 1885: Suomalaisen Kirjallisuuden Seuran keskustelemukset vv. 1883-1884. - Suomi. Kirjoituksia isänmaallisista aineista. 1885. II Jakso. 17. Osa. Helsinki: SKS. 196319.

Kirjallisuus

Andersson, Otto 1936: Framförandet av Kalevalarunorna. - Budkavlen 15(2): 65-80. 
Anttonen, Pertti J. 2005: Tradition through Modernity: Postmodernism and the Nation-State in Folklore Scholarship. Helsinki: SKS.

Aronen, Juha-Matti 2014: Viron Inkerin tanssit - Kadrelia, kasatškahia ja Viron veräjää. - Elore 21(1) [online]. < http://www.elore.fi/arkisto/1_14/aronen.pdf > [2.7.2014.]

Baker, Carolyn 2004: Membership Categorization and Interview Accounts. - Silverman, David (ed.), Qualitative Research: Theory, Method, and Practice. London: SAGE. 162-176.

Barthes, Roland 1977: Rhetoric of the Image. - Barthes, Roland, Image - Music - Text. Essays selected and translated by Stephen Heath. New York: Hill and Wang. 32-51. [1964]

Benjamin, Walter 2008: The Work of Art in the Age of Mechanical Reproduction. London: Penguin Books. [1936]

Eglin, Peter \& Hester, Stephen 2003: The Montreal Massacre: a Story of Membership Categorization Analysis. Waterloo: Wilfrid Laurier University Press.

Eskola, Katarina (toim.) 2003: Autius lehtipuissa. Elsa Enäjärvi-Haavion ja Martti Haavion päiväkirjat ja kirjeet 1942-1951. Parielämäkerran päätösosa. Helsinki: WSOY.

Garfinkel, Harold 1967: Studies in Ethnomethodology. Englewood Cliffs: Prentice-Hall.

Grossberg, Lawrence 2010: Cultural Studies in the Future Tense. Durham: Duke University Press.

Haavio, Martti 1931: Kansanrunouden keruu ja tutkimus. Helsinki: SKS.

Haavio, Martti 1939: Huomioita suomalaisen kansanperinteen kartoittamisesta. - Virittäjä 43: 33-67.

Haltsonen, Sulo 1947: Karjalainen kansantutkija. Theodor Schvindtin elämä. Porvoo: WSOY.

Harju, Maarit 1989: Samuli Paulaharju. Ruijanrannan reppuherra. Helsinki: SKS.

Hautala, Jouko 1954: Suomalainen kansanrunoudentutkimus. Helsinki: SKS.

Heikel, Axel Olai 1888a: Die Gebäude der Čeremissen, Mordwinen, Esten und Finnen. - Suomalais-ugrilaisen Seuran vuosikirja 4. Helsinki: Suomalais-ugrilainen Seura.

Heikel, Axel Olai 1989: Museomiehen päiväkirjasta. A. O. Heikelin lehtikirjoituksia. - Lehtinen, Ildikó (toim.). Helsinki: Museovirasto. 
Heritage, John 1996: Harold Garfinkel ja etnometodologia. Helsinki: Gaudeamus.

Hilbert, Richard A. 1992: The Classical Roots of Ethnomethodology: Durkheim, Weber, and Garfinkel. Chapel Hill: The University of North Carolina Press.

Ingold, Tim 2011: Introduction. - Ingold, Tim (ed.), Redrawing Anthropology: Materials, Movements, Lines. Farnham: Ashgate. 1-20.

Jewitt, Carey 2009a: An Introduction to Multimodality. - Jewitt, Carey (ed.), The Routledge Handbook of Multimodal Analysis. London: Routledge. 14-27.

Jewitt, Carey 2009b: Different approaches to Multimodality. - Jewitt, Carey (ed.), The Routledge Handbook of Multimodal Analysis. London: Routledge. 28-39.

Jokinen, Arja, Juhila, Kirsi \& Suoninen, Eero 2012: Kategoriat, kulttuuri \& moraali. Johdatus kategoria-analyysiin. Tampere: Vastapaino.

Järviluoma, Helmi \& Roivainen, Irene 1997: Jäsenkategorisoinnin analyysi kulttuurisena metodina. - Sosiologia 34(1): 15-25.

Järvinen, Irma-Riitta 1991: Elsa Enäjärvi-Haavio (1901-1951). Kinnunen, Eeva-Liisa (toim.), Sata vuotta suomalaista folkloristiikkaa. Helsinki: Helsingin yliopiston folkloristiikan laitos. 44-48.

Knapas, Rainer \& Koistinen, Pertti 1993: Historiallisia kuvia. Suomi vanhassa grafiikassa. Helsinki: SKS.

Knuuttila, Seppo 1978: Akseli Gallen-Kallelan Väinämöiset. Helsinki: SKS.

Knuuttila, Seppo 1994: Etnometodologia suullisen perinteen strategiana ja tutkimusotteena. - Knuuttila, Seppo, Tyhmän kansan teoria. Näkökulmia menneestä tulevaan. Helsinki: SKS. 68-80.

Knuuttila, Seppo 1999: Sankariaika suomalaisessa kansanrunoudentutkimuksessa 1930-luvulla. - Karkama, Pertti \& Koivisto, Hanne (toim.), Ajan paineessa. Kirjoituksia 1930-luvun suomalaisesta aatemaailmasta. Helsinki: SKS. 101-129.

Knuuttila, Seppo 2010: Myytit, mielikuvat ja Taiteilijoiden Kalevala. Knuuttila, Seppo, Piela, Ulla \& Tarkka, Lotte (toim.), Kalevalamittaisen runon tulkintoja. Helsinki: SKS. 385-393.

Knuuttila, Seppo 2011: Etnografiset käänteet perinnetieteiden yhdistäjänä? - Nieminen, Aila, Olsson, Pia, Ruotsala, Helena \& Siivonen, 
Katriina (toim.), Aineen taikaa. Näkyvän ja näkymättömän kulttuurin jäljillä. Helsinki: SKS. 330-346.

Korolainen Kari 2012: Koristelun kuvailu. Kategorisoinnin analyysi. Joensuu: Itä-Suomen yliopisto.

Kress, Gunther 2009: What is mode? - Jewitt, Carey (ed.), The Routledge Handbook of Multimodal Analysis. London: Routledge. 54-67.

Kress, Gunther 2010: Multimodality: A Social Semiotic Approach to Contemporary Communication. London: Routledge.

Kress, Gunther \& van Leeuwen, Theo 2006: Reading Images: The Grammar of Visual Design. London: Routledge.

Kupiainen, Reijo 2007: Voiko kuvaa lukea? Visuaalisen lukutaidon kysymyksiä. - Rossi, Leena-Maija \& Seppä, Anita (toim.), Tarkemmin katsoen. Visuaalisen kulttuurin lukukirja. Helsinki: Gaudeamus. 36-54.

Kuusi, Matti 1949: Tutkimus kansanrunojen esittämistavoista. - Virittäjä 53: $152-153$.

Laaksonen, Pekka 1999: Samuli Paulaharju Karjalan kankahilla. Knuuttila, Seppo, Piela, Ulla \& Timonen, Senni (toim.), Kotimailla. Helsinki: SKS. 163-183.

Lehtinen, Ildikó 2004: Agathon Reinholm - suomalainen taiteilija sukukansojen parissa. - Suomen Museo 111: 47-60.

Lehtipuro, Outi 1974: Trends in Finnish Folkloristics. - Leino, Pentti (ed.), Finnish Folkloristics 2. Helsinki: SKS. 7-36.

Lehtipuro, Outi 1983: Trends in Nordic Folkloristics. - Honko, Lauri \& Laaksonen, Pekka (eds.), Trends in Nordic Tradition Research. Helsinki: SKS. 208-223.

Lehtonen, Juhani U. E. 1972: U. T. Sirelius ja kansatiede. Helsinki: Suomen muinaismuistoyhdistys.

Leppälahti, Merja 2005: "Leikkitohtori" Elsa Enäjärvi-Haavio. - Saarikoski, Helena (toim.), Leikkikentiltä. Lastenperinteen tutkimuksia 2000-luvulta. Helsinki: SKS. 34-48.

Lynch, Michael 1985: Art and Artifact in Laboratory Science: a Study of Shop Work and Shop Talk in a Research Laboratory. London: Routledge \& Kegan Paul.

Lynch, Michael 1991: Pictures of Nothing? Visual Construals in Social Theory. - Sociological Theory 9(1): 1-21. 
Marcus, George E. 1994: The Modernist Sensibility in Recent Ethnographic Writing and the Cinematic Metaphor of Montage. - Taylor, Lucien (ed.), Visualizing Theory: Selected Essays from V. A. R. 1990-1994. New York: Routledge. 35-53.

Mikkonen, Kai 2005: Kuva ja Sana. Kuvan ja sanan vuorovaikutus kirjallisuudessa, kuvataiteessa ja ikonoteksteissä. Helsinki: Gaudeamus.

Mitchell, W. J. T. 1994: Picture Theory: Essays on Verbal and Visual Representation. Chicago: The University of Chicago Press.

Morphy, Howard \& Banks, Marcus 1997: Introduction: Rethinking Visual Anthropology. - Banks, Marcus \& Morphy, Howard (eds.), Rethinking Visual Anthropology. New Haven: Yale University Press. $1-35$.

Niiranen, Timo 1987: Axel Olai Heikel. Suomalais-ugrilaisen kansatieteen ja arkeologian tutkija. Kuopio: Kustannuskiila Oy.

Niiranen, Timo 1992: Pioneers of Finnish Ethnology. - Räsänen, Matti (ed.), Pioneers: the History of Finnish Ethnology. Helsinki: SKS. 2140.

Pirinen, Hanna 2012: Kuka keksi "taiteen" ja "taiteilijan"? Suomenkielisen taidehistoriallisen oppisanaston syntyvaiheita. - Suomen Museo 118: 86-106.

Potter, Jonathan 1996: Representing Reality: Discourse, Rhetoric and Social Construction. London: SAGE.

Pöysä, Jyrki 1989: Uusi kansanelämä suomalaisen folkloristiikan tutkimuskohteena. Toimittajan alkusanat. - Pöysä, Jyrki (toim.), Betoni kukkii. Kirjoituksia nykyperinteestä. Helsinki: SKS. 7-16.

Relander, Oskar 1894: Kuvakielestä vanhemmassa suomalaisessa lyyrillisessä kansanrunoudessa. Akateeminen väitöskirja. Helsinki: SKS.

Sarmela, Matti 1965: Kansankulttuurin kartoittamisesta. - Virittäjä 69: 255-279.

Schvindt, Theodor 1888a: Kotimaan kirjallisuutta. A. O. Heikel, Rakennukset Tsheremisseillä (...). Die Gebäude der Čeremissen (...). Kansatieteellinen sanasto (...). - Valvoja 8(10): 459-467.

Schvindt, Theodor 1888b: Hra A. O. Heikelin vastauksen johdosta. Valvoja 8(12): 594.

Seppä, Anita 2007: Kulttuurin kuvallistuminen. Teknologisoitumisen seuraus vai teoreettinen ylilyönti? - Rossi, Leena-Maija \& Seppä, 
Anita (toim.), Tarkemmin katsoen. Visuaalisen kulttuurin lukukirja. Helsinki: Gaudeamus Helsinki University Press. 14-35.

Sievänen-Allen, Ritva 1993: Tyttö venheessä. Elsa Enäjärvi-Haavion elämä 1901-1951. Porvoo: WSOY.

Sihvo, Hannes 2003: Karjalan kuva. Karelianismin taustaa ja vaiheita autonomian aikana. Helsinki: SKS. [1973]

Siikala, Anna-Leena 2013: Itämerensuomalaisten mytologia. Helsinki: SKS.

Sinisalo, Hannu 2005: Kuva tutkimuksen välineenä ja kohteena. Korkiakangas, Pirjo, Olsson, Pia \& Ruotsala, Helena (toim.), Polkuja etnologian menetelmiin. Helsinki: Ethnos ry. 206-232.

Sulkunen, Irma 2004: Suomalaisen Kirjallisuuden Seura 1831-1892. Helsinki: SKS.

Sääskilahti, Nina 1997: Kansa ja tiede. Suomalainen kansatiede ja sen kohde 1800-luvulta 1980-luvulle. Jyväskylä: Jyväskylän yliopisto, etnologian laitos.

Sääskilahti, Nina 1999: Kansan kulttuurista arkipäivän merkityksiin. Lönnqvist, Bo, Kiuru, Elina \& Uusitalo, Elina (toim.), Kulttuurin muuttuvat kasvot. Johdatusta etnologiatieteisiin. Helsinki: SKS. 145-154.

Söderholm, Stig 1982: Kamera kenttätyössä: kuvadokumentit ja visuaalinen metodiikka. - Suojanen, Päivikki \& Saressalo, Lassi (toim.), Kulttuurin kenttätutkimus. Tampere: Tampereen yliopiston kansanperinteen laitos. 227-234.

Tirranen, Hertta 1960: Agathon Reinholm. - Kalevalaseuran vuosikirja 40. Porvoo: WSOY. 68-81.

Turunen, Risto 1995: Historiaa ja runoutta. Kertomus suomalaisista perinnetieteistä, niiden paradigmoista, retoriikasta ja institutionaalisista jännitteistä. Julkaisematon kulttuuriantropologian sivulaudatur-tutkielma. Joensuu: Joensuun yliopisto, suomen kielen ja kulttuuritieteiden laitos.

Turunen, Risto 1996: Syrjästä. Huomioita kahdesta perinnetieteen tutkijasta. - Kortelainen, Kaisu \& Vakimo, Sinikka (toim.), Tradition edessä. Kirjoituksia perinteestä ja kulttuurista. Joensuu: Suomen Kansantietouden Tutkijain Seura. 78-94.

Vakimo, Sinikka 2008: Folkloristiikan ikäparadigmoista - kokeilu tieteenalan ihmiskuvan toisin katsomiseksi. - Elore 15(1) [online]. < http://www.elore.fi/arkisto/1_08/vak1_08.pdf > [2.7.2014.] 
Vuorela, Toivo 1977: Ethnology in Finland Before 1920. Helsinki: Societas Scientiarium Fennica.

Väisänen, A. O. 1948: Kalevalanmitallisten runojen esitystavat. Kalevalaseuran vuosikirja 27-28. Porvoo: WSOY. 184-243.

Väisänen, A. O. 1990: "Lyökämme käsi kätehen". - Pekkilä, Erkki (toim.), Hiljainen haltioituminen. A. O. Väisäsen tutkielmia kansanmusiikista. Helsinki: SKS. 84-88. [1949]

Wilson, William A. 1985: Kalevala ja kansallisuusaate. Helsinki: Työväen Sivistysliitto.

Filosofian tohtori Kari Korolainen on perinteentutkimuksen post doc -tutkija Itä-Suomen yliopistossa. 